\title{
Altered fractionation radiotherapy with or without chemotherapy in the treatment of head and neck cancer: a network meta-analysis
}

\author{
Yingyu Liu' \\ Changgui Kou' \\ Wei Bail \\ Xinyu Liu' \\ Yan Song' \\ Lili Zhang' \\ Mohan Wang' \\ Yangyu Zhang' \\ Yueyue You' \\ Yue Yin² \\ Xin Jiang ${ }^{3}$ \\ Ying $\mathrm{Xin}^{4}$
}

'Department of Epidemiology and Biostatistics, School of Public Health, Jilin University, Changchun, Jilin, China; ${ }^{2}$ Department of Radiation Oncology,

The Second Affiliated Hospital of Harbin Medical University, Harbin, Heilongjiang, China; ${ }^{3}$ Department of Radiation Oncology, The First Hospital of Jilin University, Changchun, Jilin, China; ${ }^{4}$ Department of Pathology, School of Basic Medicine, Jilin University, Changchun, Jilin, China
This article was published in the following Dove Press journal: OncoTargets and Therapy

\begin{abstract}
Objectives: A Bayesian network meta-analysis (NMA) was conducted in patients with head and neck cancers (HNCs) to estimate the efficacy and safety of treatment with conventional fractionation radiotherapy (CF), conventional fractionation chemoradiotherapy (CF_CRT), hyperfractionated radiotherapy (HF), hyperfractionated chemoradiotherapy (HF_CRT), accelerated fractionation radiotherapy, accelerated fractionation chemoradiotherapy, accelerated hyperfractionated radiotherapy (HART) or accelerated hyperfractionated chemoradiotherapy (HACRT) to identify superior treatments to aid in clinical decisions.

Methods: PubMed, EMBASE and the Cochrane Central Register of Controlled Trials (CENTRAL) were searched for potentially eligible randomized controlled trials up to December 2016. Overall survival (OS), disease-free survival (DFS) and locoregional control (LRC) were considered efficacy outcomes, whereas acute toxicity and late toxicity on skin and mucosa were considered safety outcomes. The surface under the cumulative ranking curve (SUCRA) was calculated to rank each treatment in each index.
\end{abstract}

Results: Data from 72 trials with 21,868 participants were included in the analysis. Concerning OS, all treatments were associated with a significant advantage compared to CF alone, with HR effect sizes ranging from 0.64 to 0.83 , and HACRT was significantly more effective than all the other treatments. The network comparisons of both HACRT vs HART and HF_CRT vs HF demonstrated a higher OS benefit, with an HR of 0.78 (95\% credible interval [CrI]: 0.64-0.95) and 0.78 (95\% CrI: 0.61-0.99), respectively. The results of SUCRA indicated that HACRT had the best ranking for OS and LRC, HF_CRT for DFS, HART for acute and late skin toxicity, CF_CRT for acute mucosal toxicity and HF_CRT for late mucosal toxicity.

Conclusion: The NMA results support the notion that HACRT is the preferable treatment modality for HNCs because it has better rankings in all three efficacy indexes, although it does present a high risk of acute mucosal toxicity.

Keywords: altered fractionation radiotherapy, head and neck cancer, randomized controlled trials, network meta-analysis

\section{Introduction}

Head and neck cancers (HNCs) represent the sixth most common carcinoma worldwide, with an estimated incidence of $>500,000$ new cases each year. ${ }^{1-3}$ They are also a major oncologic burden in developing countries (age-standardized rate of incidence of 10-30/100,000). ${ }^{4}$ There are various treatments for HNCs, including postoperative radiotherapy, chemoradiotherapy, radical radiotherapy and induction chemotherapy, followed by concurrent chemoradiotherapy and bio-radiotherapy which are developed recently. ${ }^{5}$ Since X-rays were invented by WC Roentgen in 1895 , 
radiation has been used for different malignancies and for benign conditions. However, the concept of fractionation was unknown. Thor Stenbeck used a treatment to cure skin cancer in which small doses of radiation were given each day, which was subsequently called "fractionation radiotherapy" ${ }^{6}$ Later studies by Coutard showed that protracted fractionation in throat cancers resulted in tolerance of the skin and mucous membranes as well as improvement in the tumor response. ${ }^{7}$ Conventional fractionation radiotherapy (CF) with 1.8-2.0 Gy per fraction was found to give good local control and lead to low normal tissue complication rates. ${ }^{8}$ Different fractionation schedules came into practice with a better understanding of the "four Rs" of radiobiology and biologically effective doses. Since the 1980s, different radiotherapy methods have been developed, including altered fractionation radiotherapy, hyperfractionated radiotherapy (HF), accelerated fractionation radiotherapy (AF), accelerated hyperfractionated radiotherapy (HART), hypofractionation and combinations of these. ${ }^{9}$ The differences between these unconventional fractionation radiotherapy methods depend on their doses and the amount of time. HF is delivered through a greater number of smaller treatment doses. In AF, radiotherapy is delivered in lesser amount of time, with greater number of treatments per day. In HART, the number of treatments per day and treatment doses are greater. In hypofractionation, the number of fractions that are delivered are decreased by increasing daily treatment doses. ${ }^{10}$ Many modified fractionation schemes have shown an improvement in overall survival (OS) and locoregional control (LRC) compared to standard fractionation in randomized clinical trials. ${ }^{11-18}$ Several meta-analyses have compared two different radiotherapy methods with or without chemotherapy. ${ }^{19-23}$ However, randomized comparisons of all these strategies have not been carried out so far. This study adopted network meta-analysis (NMA) to conduct a comprehensive comparative analysis of the efficacy and safety of various altered fractionation radiotherapy strategies or their combinations with chemotherapy based on published original literature, aiming to provide evidence for clinical decision making.

\section{Methods}

\section{Search strategies and study selection}

PubMed, EMBASE and the Cochrane Central Register of Controlled Trials (CENTRAL) were searched for potentially eligible studies published from inception to December 2016. Search terms were the combination of subject words and free words of the keywords "head and neck cancer", "hyperfraction*", "accelerated fractionation*" and "Randomized Controlled Trial". The details of the search strategies for every database are provided in the Supplementary materials. In addition, we scanned the reference lists of the existing systematic reviews and meta-analyses relevant to this NMA for additional trials. We restricted the language to English.

The titles and abstracts were identified, and the full texts of potentially eligible studies were reviewed in duplicate by two reviewers (Yingyu Liu and Yangyu Zhang) independently. We conducted the meta-analysis and reported the results according to the PRISMA statement.

\section{Inclusion and exclusion criteria}

To be eligible, trials were required to meet the following inclusion criteria:

1) Study objective: Patients with HNCs, which were defined according to the Medical Subject Headings categories, including oral cavity, oropharyngeal, hypopharyngeal, laryngeal, esophageal and nasopharyngeal carcinomas, were eligible.

2) Study intervention: Comparison between altered fractionation radiotherapy (accelerated or/and hyperfractionated) with or without chemotherapy and conventional radiotherapy (1.8-2.0 Gy/fraction per day for 5 days/week), or to be specific, comparison between $\mathrm{CF}$, conventional fractionation chemoradiotherapy (CF_CRT), HF, hyperfractionated chemoradiotherapy (HF_CRT), AF, accelerated fractionation chemoradiotherapy (AF_CRT), HART or accelerated hyperfractionated chemoradiotherapy (HACRT) was eligible for analysis.

3) Outcome parameters: OS, disease-free survival (DFS) and LRC were the indexes used to evaluate the efficacy. The assessment of safety included acute and late toxicity on skin and mucosa. Radiotherapy-related toxicities were graded according to the Acute and Late Scoring Criteria of the Radiation Therapy Oncology Group and the European Organization for Research and Treatment of Cancer, ${ }^{24}$ and chemotherapy-related toxicities were scored using the WHO criteria. ${ }^{25}$ Incidence of toxicities of grade $\geq 3$ was recorded.

4) Study design: Randomized controlled trials were included for analysis. Trials were excluded if they were: conference papers or abstracts; duplicates, as confirmed by the trial number; confounded by additional therapeutic differences, such as a monoclonal antibody or sensitizer; or with incomplete outcome data, selective reporting or other obvious bias. 


\section{Data extraction and quality assessment}

Data extraction and quality assessment were performed independently by at least two of six reviewers (Yingyu Liu, Xinyu Liu, Wei Bai, Yueyue You, Yan Song and Lili Zhang). The data collected for all patients included age, sex, tumor site, stage or $\mathrm{T}$ and $\mathrm{N}$ classification, histology, performance status, allocated treatment details and outcomes. The primary end point of our NMA was OS, as defined from the time of randomization or the start of treatment to death from any cause. For OS, DFS and LRC, HRs and their 95\% CIs were used to estimate treatment effects. If the reported data were insufficient, we estimated the HR and $95 \%$ CI or extracted data from OS curves of treatment effects with methods as described by Parmar et $\mathrm{al}^{26}$ and Tierney et $\mathrm{al}^{27}$ using Engauge Digitizer software version 4.1.

We assessed the risk of bias according to the Cochrane Handbook for Systematic Reviews of Interventions (Version 5.0.0), ${ }^{28}$ including the following items: generation of a randomization sequence, allocation concealment, blinding, incomplete outcome data, selective reporting and other bias.

\section{Statistical analyses}

To compare the relative effects and safety of altered fractionation radiotherapy with or without chemotherapy in the treatment of HNC, we conducted an NMA in a Bayesian framework. The random-effects model was adopted. BrooksGelman-Rubin and trace plots were used to diagnose and assess the convergence of models. Four chains were fit with 20,000 burn-ins and 5,000 iterations each. We used the HR and its $95 \%$ credible interval $(\mathrm{CrI})$ to measure the relative efficacy size with log-transformed HRs from each trial and the corresponding standard errors, while for binary outcomes, the safety was assessed with risk ratio (RR) and 95\% CrI. A significantly increased HR or RR (HR or RR $>1$ ) suggested that one therapy may be less efficacious and safer than another, and a 95\% CrI in that range did not include 1, indicating a statistically significant difference and vice versa. CrIs can be interpreted as conventional CIs in the presence of minimally informative priors.

NMA also provided a ranking probability of each treatment if the probability of each arm achieving the best rank among all treatments was calculated. The surface under the cumulative ranking curve (SUCRA) was computed to help identify the most appropriate treatment for each outcome. A larger SUCRA value represented a better rank. In the forest plots, we ranked the effects of the treatment regimens according to SUCRA values. Furthermore, node-splitting models were adopted to test the inconsistency of each comparison, and a $P$-value $<0.05$ indicated the significance of the inconsistency. All the analyses were performed with the R 3.4.1 packages "Gemtc" and JAGS.

\section{Results \\ Search results}

The search strategy identified 2,082 studies, and through reviewing the reference lists of all eligible articles and relevant systematic reviews, we identified 24 additional studies. After excluding duplicate studies, screening titles and abstracts and reading full texts, 72 studies with 21,868 participants were included in the analysis. PRISMA flowcharts are shown in Figure 1. Within the included studies, $40(55.6 \%)$ provided the details about randomization methods, and most studies did not describe the details of blinding and concealment. The details of all the 72 articles are described in Table $\mathrm{S} 1$.

\section{Network results}

The networks of eligible comparisons on the primary outcome, OS, are shown in Figure 2. The size of the nodes reflects the number of corresponding trials. The lines link the direct comparisons, and the thickness of the lines represents the number of trials comparing the two therapies. The network plot indicated that $\mathrm{CF}$ was included in the largest number of comparisons and that $\mathrm{AF}$ was included in the second largest number of comparisons. Although comparisons of AF and CF were common, few comparisons of AF_CRT and HF_CRT were identified.

We created hierarchies of effect size based on SUCRA rankings for all outcomes. All outcomes were outlined in the form of forest plots with all therapies compared to CF using the value of HRs with $95 \%$ CrIs. The complete results were recorded in the accompanying tables.

\section{Efficacy outcomes}

OS is the primary indicator of the efficacy. The Bayesian NMA demonstrated that all treatments were superior to $\mathrm{CF}$ alone, with HR effect sizes ranging from 0.64 to 0.83 , and HACRT was significantly more effective than all the other treatments. Network comparisons of HACRT vs HART and HF_CRT vs HF showed a statistically significant OS benefit with an HR of 0.78 (95\% CrI: 0.64-0.95) and $0.78(95 \% \mathrm{CrI}$ : 0.61-0.99), respectively (Table 1 and Figure $3 \mathrm{~A}$ ). The results of node-splitting analysis of inconsistency indicated that the direct and indirect treatment effects between AF_CRT and $\mathrm{CF}(P=0.02)$ were inconsistent. 


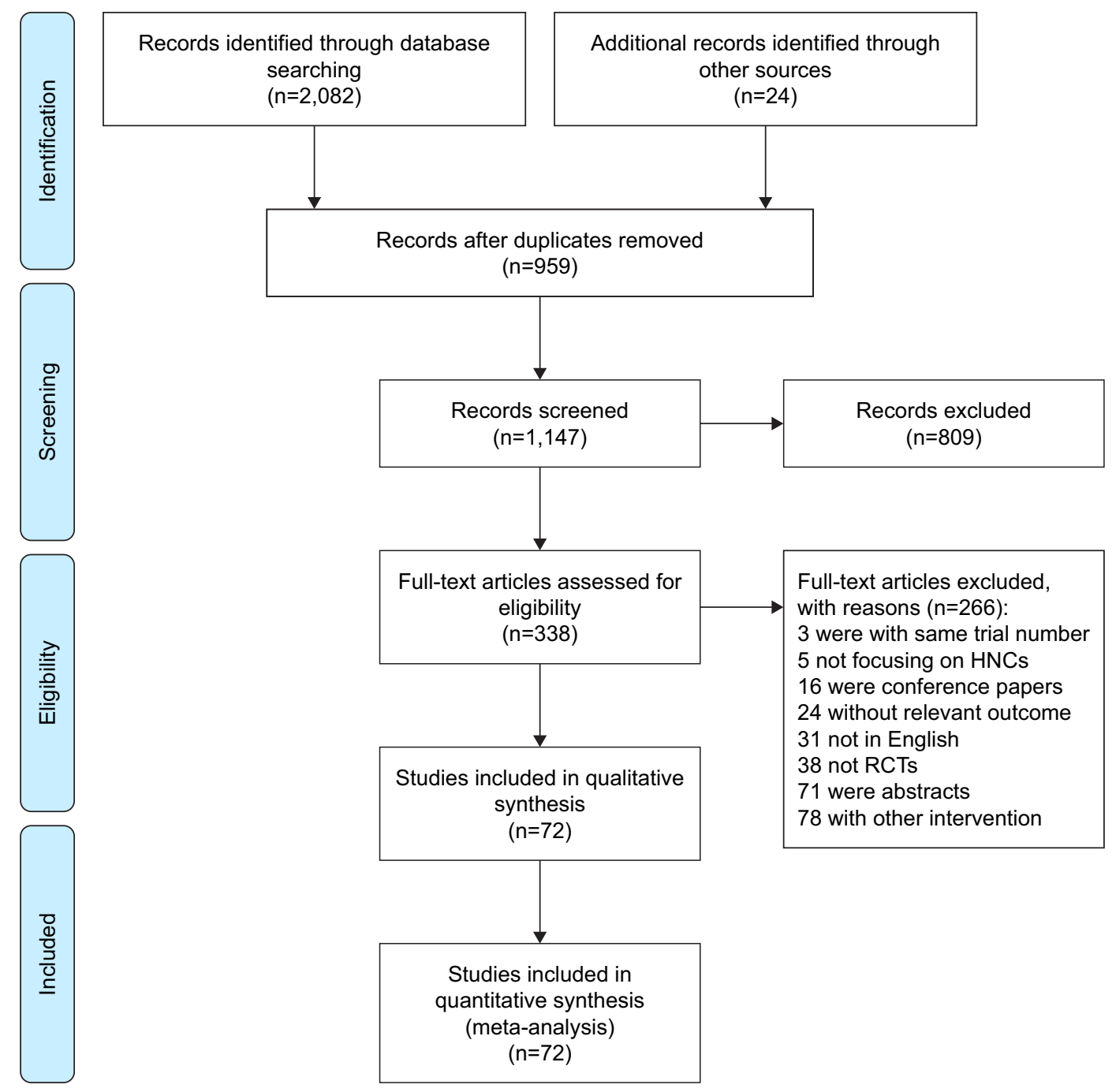

Figure I PRISMA flow diagram.

Abbreviations: HNCs, head and neck cancers; RCTs, randomized controlled trials.

For DFS, HF_CRT, CF_CRT and AF conferred an advantage over CRT alone: the HRs (and corresponding 95\% CrIs) were $0.56(0.34-0.92), 0.76(0.61-0.96)$ and 0.86 (0.76-0.97), respectively. The results also suggested a favorable DFS benefit of HF_CRT compared with HF (HR: 0.62, 95\% CrI: 0.39-0.99). The SUCRA results depicted that the prognosis of HNC patients treated with HF_CRT was the best (SUCRA $=89.3 \%$ ) (Table 1 and Figure 3B). No evidence of significant differences between direct and indirect comparisons was detected $(P>0.05)$.

Data on LRC were available for 43 trials. From the results, when compared with $\mathrm{CF}$, HACRT, HART and AF demonstrated significantly higher LRC (HR: $0.53,95 \%$ CrI: 0.37-0.74; HR: 0.75, 95\% CrI: 0.58-0.96; and HR: 0.78, 95\% CrI: 0.69-0.86, respectively). HART, AF, HF and CF_CRT were not significantly better than HACRT, with a range of significant mean HRs of 1.43-1.70. According to the rankings associated with the SUCRA values, HACRT was the most preferable treatment, with a SUCRA value of $91.3 \%$, whereas AF_CRT and HF_CRT ranked second and third (SUCRA: $68.0 \%$ and $66.7 \%$, respectively) (Table 2 and Figure 3C). Investigation of inconsistencies between direct and indirect evidence with node-splitting models detected that there were inconsistencies between $\mathrm{AF}$ and $\mathrm{CF}(P=0.003), \mathrm{AF}$ and CF_CRT $(P=0.004)$ and $\mathrm{CF}$ and $\mathrm{CF} \_\mathrm{CRT}(P=0.002)$.

\section{Safety outcomes}

Acute toxicity and late toxicity could reflect the safety characteristics of the treatments. We assessed acute and late toxicity on skin and mucosa. With respect to serious (grade $\geq 3$ ) acute skin toxicity, compared with CF, HF (RR: 1.60, 95\% CrI: 1.06-2.40) and AF_CRT (RR: 1.62, 95\% CrI: 1.11-2.51) 


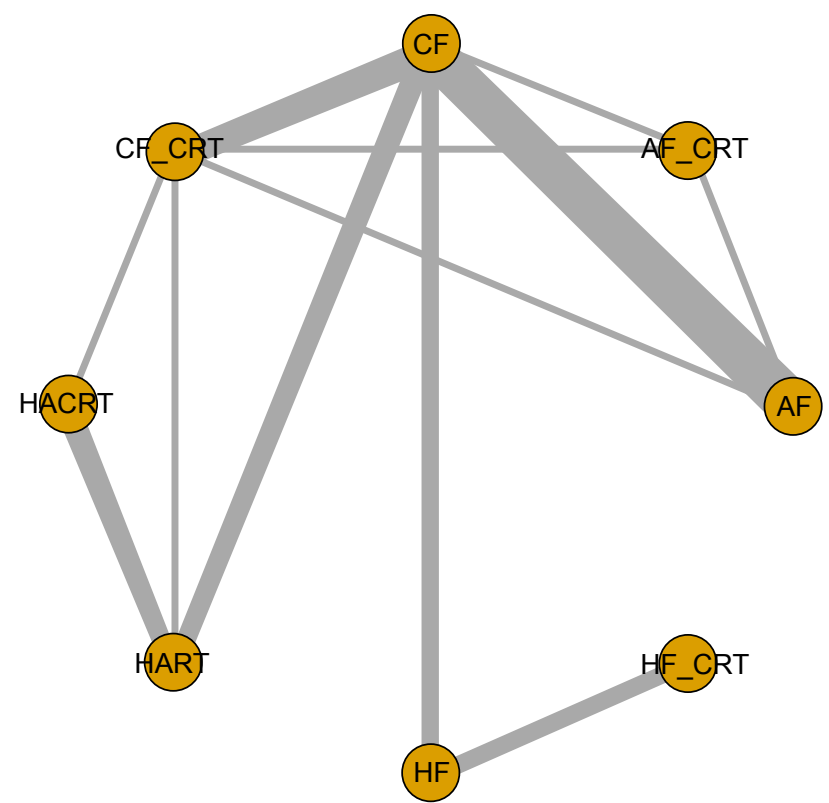

Figure 2 Network plot for all the treatments included in the network metaanalysis.

Abbreviations: CF, conventional fractionation radiotherapy; CF_CRT, conventional fractionation chemoradiotherapy; HF, hyperfractionated radiotherapy; HF_CRT, hyperfractionated chemoradiotherapy; AF, accelerated fractionation radiotherapy; AF_CRT, accelerated fractionation chemoradiotherapy; HART, accelerated hyperfractionated radiotherapy; HACRT, accelerated hyperfractionated chemoradiotherapy.

were significantly associated with an increased risk, whereas AF_CRT yielded more acute skin toxicity than CF_CRT (RR: $1.47,95 \%$ CrI: 1.05-2.26). For acute mucosal toxicity, $\mathrm{CF}$ showed a strong and favorable benefit compared with other treatments, with a mean RR effect size ranging from 0.38 to 0.94 ; HART and CF_CRT were not statistically significant (Table 3). The top three treatments ranked by their SUCRA values were HART (84.5\%), HACRT (74.4\%) and CF (67.5\%) for acute skin toxicity, and CF (94.7\%), CF_CRT (88.5\%) and HART (54.1\%) for acute mucosal toxicity. For late toxicity, only HF (RR: 3.26, 95\% CrI: 1.38-8.31) was significantly associated with an increased risk for late mucosal toxicity compared with CF_CRT. No other significant difference was observed among other intervention comparison groups for late toxicity (Table 4). As shown in Figure 4, HF_CRT and HART had the highest probability of being the treatment approaches with the least amount of toxicity on skin and mucosa for HNCs, as their SUCRA values were $82.8 \%$ and $54.9 \%$, respectively.

For acute skin toxicity, late skin toxicity and late mucosal toxicity, significant inconsistencies between direct and indirect evidence were not found among the various treatment comparisons. However, with respect to acute mucosal toxicity, the direct and indirect treatment effects between AF_CRT and $\mathrm{AF}(P=0.012)$ and $\mathrm{CF} \_\mathrm{CRT}$ and $\mathrm{AF}(P=0.032)$ seemed to be inconsistent.

\section{Discussion}

Surgery is the mainstream treatment for patients with HNCs, but it leads to poor results. In attempts to improve patient outcomes, various forms of chemotherapy, radiotherapy, targeted therapy and immunotherapy have been introduced.

Table I OS and DFS of treatments for head and neck cancer (HR [95\% Crl])

\begin{tabular}{|c|c|c|c|c|c|c|c|c|}
\hline & DFS & & & & & & & \\
\hline \multirow[t]{8}{*}{ os } & $\mathrm{CF}$ & $\begin{array}{l}1.58 \\
(0.85-2.98)\end{array}$ & $\begin{array}{l}1.79 \\
(1.09-2.95)\end{array}$ & $\begin{array}{l}1.31 \\
(1.04-1.65)\end{array}$ & $\begin{array}{l}1.29 \\
(0.84-1.97)\end{array}$ & $\begin{array}{l}1.16 \\
(1.03-1.32)\end{array}$ & $\begin{array}{l}1.10 \\
(0.95-1.32)\end{array}$ & $\begin{array}{l}1.06 \\
(0.92-1.38)\end{array}$ \\
\hline & $\begin{array}{l}0.64 \\
(0.50-0.83)\end{array}$ & HACRT & $\begin{array}{l}1.14 \\
(0.5 I-2.46)\end{array}$ & $\begin{array}{l}0.83 \\
(0.43-1.55)\end{array}$ & $\begin{array}{l}0.82 \\
(0.39-1.66)\end{array}$ & $\begin{array}{l}0.74 \\
(0.39-1.38)\end{array}$ & $\begin{array}{l}0.70 \\
(0.37-1.33)\end{array}$ & $\begin{array}{l}0.68 \\
(0.37-1.26)\end{array}$ \\
\hline & $\begin{array}{l}0.64 \\
(0.46-0.88)\end{array}$ & $\begin{array}{l}0.99 \\
(0.66-\mid .5 I)\end{array}$ & HF_CRT & $\begin{array}{l}0.74 \\
(0.42-1.27)\end{array}$ & $\begin{array}{l}0.72 \\
(0.37-1.37)\end{array}$ & $\begin{array}{l}0.65 \\
(0.39-1.08)\end{array}$ & $\begin{array}{l}0.62 \\
(0.39-0.99)\end{array}$ & $\begin{array}{l}0.60 \\
(0.36-1.06)\end{array}$ \\
\hline & $\begin{array}{l}0.71 \\
(0.60-0.83)\end{array}$ & $\begin{array}{l}1.10 \\
(0.83-1.46)\end{array}$ & $\begin{array}{l}\text { I.II } \\
(0.78-1.58)\end{array}$ & CF_CRT & $\begin{array}{l}0.98 \\
(0.68-\mid .4 I)\end{array}$ & $\begin{array}{l}0.89 \\
(0.70-1.14)\end{array}$ & $\begin{array}{l}0.84 \\
(0.64-1.13)\end{array}$ & $\begin{array}{l}0.81 \\
(0.63-1.14)\end{array}$ \\
\hline & $\begin{array}{l}0.73 \\
(0.58-0.90)\end{array}$ & $\begin{array}{l}1.13 \\
(0.81-1.57) \\
\end{array}$ & $\begin{array}{l}1.14 \\
(0.77-1.68) \\
\end{array}$ & $\begin{array}{l}1.02 \\
(0.82-1.28) \\
\end{array}$ & AF_CRT & $\begin{array}{l}0.90 \\
(0.59-\mid .4 I) \\
\end{array}$ & $\begin{array}{l}0.86 \\
(0.55-1.38) \\
\end{array}$ & $\begin{array}{l}0.83 \\
(0.55-1.39) \\
\end{array}$ \\
\hline & $\begin{array}{l}0.81 \\
(0.72-0.91)\end{array}$ & $\begin{array}{l}1.26 \\
(0.96-1.67)\end{array}$ & $\begin{array}{l}.27 \\
(0.90-1.79)\end{array}$ & $\begin{array}{l}1.14 \\
(0.96-1.36)\end{array}$ & $\begin{array}{l}1.12 \\
(0.90-1.40)\end{array}$ & $\mathrm{AF}$ & $\begin{array}{l}0.95 \\
(0.78-1.18)\end{array}$ & $\begin{array}{l}0.91 \\
(0.76-1.22)\end{array}$ \\
\hline & $\begin{array}{l}0.82 \\
(0.66-\mid .02)\end{array}$ & $\begin{array}{l}1.28 \\
(0.92-1.80)\end{array}$ & $\begin{array}{l}1.29 \\
(1.01-1.64)\end{array}$ & $\begin{array}{l}1.16 \\
(0.89-1.52)\end{array}$ & $\begin{array}{l}1.13 \\
(0.83-1.55)\end{array}$ & $\begin{array}{l}1.01 \\
(0.79-1.30)\end{array}$ & $\mathrm{HF}$ & $\begin{array}{l}0.96 \\
(0.78-1.31)\end{array}$ \\
\hline & $\begin{array}{l}0.83 \\
(0.68-0.99)\end{array}$ & $\begin{array}{l}1.28 \\
(1.05-1.56)\end{array}$ & $\begin{array}{l}1.30 \\
(0.89-1.87)\end{array}$ & $\begin{array}{l}1.16 \\
(0.93-1.45)\end{array}$ & $\begin{array}{l}1.14 \\
(0.86-1.50)\end{array}$ & $\begin{array}{l}1.02 \\
(0.82-1.26)\end{array}$ & $\begin{array}{l}1.01 \\
(0.75-1.33)\end{array}$ & HART \\
\hline
\end{tabular}

Notes: Treatments are reported in the order of efficacy ranking. Comparisons between treatments should be read from left to right, and the estimate is in the cell in common between the row-defining treatment and the column-defining treatment. Statistically significant results are in bold.

Abbreviations: OS, overall survival; DFS, disease-free survival; Crl, credible interval; CF, conventional fractionation radiotherapy; CF_CRT, conventional fractionation chemoradiotherapy; HF, hyperfractionated radiotherapy; HF_CRT, hyperfractionated chemoradiotherapy; AF, accelerated fractionation radiotherapy; AF_CRT, accelerated fractionation chemoradiotherapy; HART, accelerated hyperfractionated radiotherapy; HACRT, accelerated hyperfractionated chemoradiotherapy. 


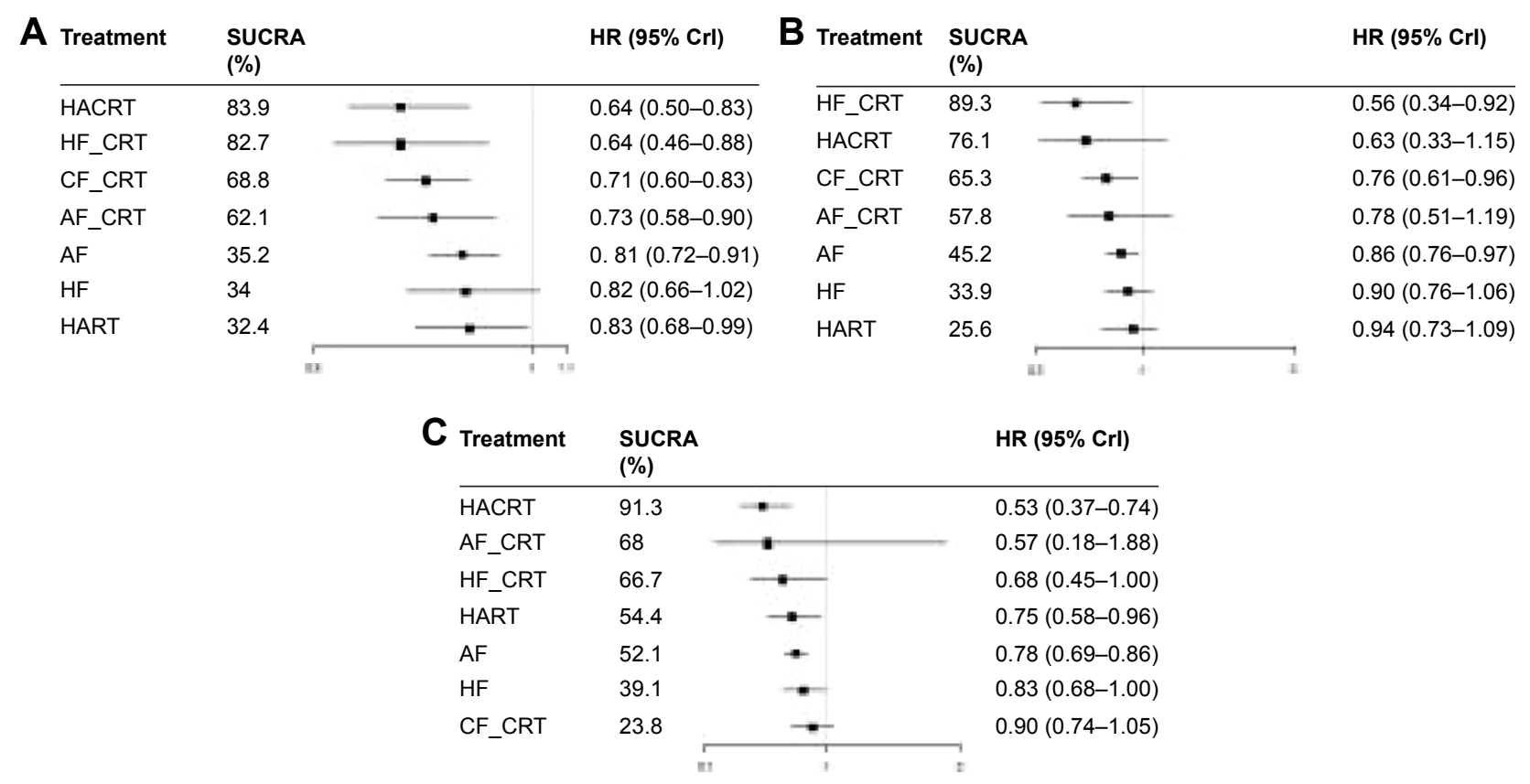

Figure 3 Forest plots of efficacy of different treatments compared with conventional fractionation radiotherapy: (A) overall survival; (B) disease-free survival; and (C) locoregional control.

Abbreviations: Crl, credible interval; CF_CRT, conventional fractionation chemoradiotherapy; HF, hyperfractionated radiotherapy; HF_CRT, hyperfractionated chemoradiotherapy; AF, accelerated fractionation radiotherapy; AF_CRT, accelerated fractionation chemoradiotherapy; HART, accelerated hyperfractionated radiotherapy; HACRT, accelerated hyperfractionated chemoradiotherapy; SURCA, surface under the cumulative ranking curve.

Over the last several decades, a large body of high-quality evidence has shown that the addition of chemotherapy to radiotherapy $y^{29,30}$ or altering the fractionation ${ }^{31,32}$ consistently and convincingly improves outcomes in locoregionally advanced HNCs. However, there is no conclusion about which one among altered fractionation radiotherapy treatments has a better prognostic effect.
The main goal of our study was to verify the efficacy (OS, DFS and LRC) and safety (acute and late toxicity on skin and mucosa) of eight treatments (CF, CF_CRT, HF, HF_CRT, AF, AF_CRT, HART and HACRT). Seventy-two papers, which included a total of 21,868 patients with HNCs, were analyzed. We chose OS, which crucially depends on the observation time, as the primary outcome for our analysis.

Table 2 LRC of treatments for head and neck cancer (HR [95\% $\mathrm{Crl}]$ )

\begin{tabular}{|c|c|c|c|c|c|c|c|}
\hline $\mathrm{CF}$ & & & & & & & \\
\hline $\begin{array}{l}0.53 \\
(0.37-0.74)\end{array}$ & HACRT & & & & & & \\
\hline $\begin{array}{l}0.57 \\
(0.18-1.88)\end{array}$ & $\begin{array}{l}1.08 \\
(0.33-3.78)\end{array}$ & AF_CRT & & & & & \\
\hline $\begin{array}{l}0.68 \\
(0.45-1.00)\end{array}$ & $\begin{array}{l}1.30 \\
(0.82-1.99)\end{array}$ & $\begin{array}{l}1.19 \\
(0.34-4.00)\end{array}$ & HF_CRT & & & & \\
\hline $\begin{array}{l}0.75 \\
(0.58-0.96)\end{array}$ & $\begin{array}{l}1.43 \\
(1.08-1.87)\end{array}$ & $\begin{array}{l}1.32 \\
(0.39-4.23)\end{array}$ & $\begin{array}{l}1.10 \\
(0.78-1.57)\end{array}$ & HART & & & \\
\hline $\begin{array}{l}0.78 \\
(0.69-0.86)\end{array}$ & $\begin{array}{l}1.48 \\
(1.03-2.11)\end{array}$ & $\begin{array}{l}1.36 \\
(0.41-4.30)\end{array}$ & $\begin{array}{l}1.14 \\
(0.77-1.73)\end{array}$ & $\begin{array}{l}1.03 \\
(0.79-1.36)\end{array}$ & $\mathrm{AF}$ & & \\
\hline $\begin{array}{l}0.83 \\
(0.68-1.00)\end{array}$ & $\begin{array}{l}1.57 \\
(1.07-2.32)\end{array}$ & $\begin{array}{l}1.45 \\
(0.43-4.64)\end{array}$ & $\begin{array}{l}1.21 \\
(0.81-1.86)\end{array}$ & $\begin{array}{l}1.10 \\
(0.8 I-I .5 I)\end{array}$ & $\begin{array}{l}1.06 \\
(0.86-1.33)\end{array}$ & $\mathrm{HF}$ & \\
\hline $\begin{array}{l}0.90 \\
(0.74-1.05)\end{array}$ & $\begin{array}{l}1.70 \\
(1.18-2.44)\end{array}$ & $\begin{array}{l}1.56 \\
(0.47-4.99)\end{array}$ & $\begin{array}{l}1.31 \\
(0.87-2.02)\end{array}$ & $\begin{array}{l}1.19 \\
(0.90-1.59)\end{array}$ & $\begin{array}{l}1.15 \\
(0.96-1.37)\end{array}$ & $\begin{array}{l}1.09 \\
(0.83-1.39)\end{array}$ & CF_CRT \\
\hline
\end{tabular}

Notes: Treatments are reported in the order of efficacy ranking. Comparisons between treatments should be read from left to right, and the estimate is in the cell in common between the row-defining treatment and the column-defining treatment. Statistically significant results are in bold.

Abbreviations: LRC, locoregional control; Crl, credible interval; CF, conventional fractionation radiotherapy; CF_CRT, conventional fractionation chemoradiotherapy; HF, hyperfractionated radiotherapy; HF_CRT, hyperfractionated chemoradiotherapy; AF, accelerated fractionation radiotherapy; AF_CRT, accelerated fractionation chemoradiotherapy; HART, accelerated hyperfractionated radiotherapy; HACRT, accelerated hyperfractionated chemoradiotherapy. 
Table 3 Acute skin toxicity and acute mucosal toxicity of treatments for head and neck cancer (RR [95\% Crl])

\begin{tabular}{|c|c|c|c|c|c|c|c|c|}
\hline & \multicolumn{8}{|c|}{ Acute mucosal toxicity } \\
\hline \multirow[t]{8}{*}{$\begin{array}{l}\text { Acute skin } \\
\text { toxicity }\end{array}$} & $\mathrm{CF}$ & $\begin{array}{l}0.66 \\
(0.42-1.03)\end{array}$ & $\begin{array}{l}0.38 \\
(0.19-0.72)\end{array}$ & $\begin{array}{l}0.94 \\
(0.73-1.22)\end{array}$ & $\begin{array}{l}0.59 \\
(0.47-0.75)\end{array}$ & $\begin{array}{l}0.63 \\
(0.46-0.86)\end{array}$ & $\begin{array}{l}0.54 \\
(0.37-0.76)\end{array}$ & $\begin{array}{l}0.58 \\
(0.34-0.97)\end{array}$ \\
\hline & $\begin{array}{l}0.70 \\
(0.28-1.58)\end{array}$ & HART & $\begin{array}{l}0.57 \\
(0.31-1.0 I)\end{array}$ & $\begin{array}{l}1.42 \\
(0.92-2.20)\end{array}$ & $\begin{array}{l}0.90 \\
(0.56-1.45)\end{array}$ & $\begin{array}{l}0.94 \\
(0.55-1.62)\end{array}$ & $\begin{array}{l}0.81 \\
(0.47-1.37)\end{array}$ & $\begin{array}{l}0.87 \\
(0.44-1.72)\end{array}$ \\
\hline & $\begin{array}{l}0.76 \\
(0.23-2.27)\end{array}$ & $\begin{array}{l}1.08 \\
(0.50-2.32)\end{array}$ & HACRT & $\begin{array}{l}2.48 \\
(1.35-4.84)\end{array}$ & $\begin{array}{l}1.57 \\
(0.82-3.17)\end{array}$ & $\begin{array}{l}1.66 \\
(0.83-3.47)\end{array}$ & $\begin{array}{l}1.43 \\
(0.71-2.93)\end{array}$ & $\begin{array}{l}1.52 \\
(0.68-3.56)\end{array}$ \\
\hline & $\begin{array}{l}\text { I.II } \\
(0.80-1.46)\end{array}$ & $\begin{array}{l}1.57 \\
(0.71-3.82)\end{array}$ & $\begin{array}{l}1.46 \\
(0.49-4.64)\end{array}$ & CF_CRT & $\begin{array}{l}0.63 \\
(0.47-0.84)\end{array}$ & $\begin{array}{l}0.67 \\
(0.45-0.98)\end{array}$ & $\begin{array}{l}0.57 \\
(0.39-0.81)\end{array}$ & $\begin{array}{l}0.61 \\
(0.35-1.08)\end{array}$ \\
\hline & $\begin{array}{l}1.14 \\
(0.85-1.53)\end{array}$ & $\begin{array}{l}1.63 \\
(0.7 I-4.14)\end{array}$ & $\begin{array}{l}I .5 \mathrm{I} \\
(0.50-5.00)\end{array}$ & $\begin{array}{l}1.03 \\
(0.76-1.45)\end{array}$ & $\mathrm{AF}$ & $\begin{array}{l}1.05 \\
(0.75-1.48)\end{array}$ & $\begin{array}{l}0.91 \\
(0.64-1.25)\end{array}$ & $\begin{array}{l}0.97 \\
(0.56-1.66)\end{array}$ \\
\hline & $\begin{array}{l}1.60 \\
(1.06-2.40)\end{array}$ & $\begin{array}{l}2.28 \\
(0.93-6.06)\end{array}$ & $\begin{array}{l}2.12 \\
(0.66-7.23)\end{array}$ & $\begin{array}{l}.44 \\
(0.93-2.32)\end{array}$ & $\begin{array}{l}1.40 \\
(0.92-2.12)\end{array}$ & $\mathrm{HF}$ & $\begin{array}{l}0.86 \\
(0.54-1.32)\end{array}$ & $\begin{array}{l}0.92 \\
(0.60-1.40)\end{array}$ \\
\hline & $\begin{array}{l}I .62 \\
(I . I I-2.5 I)\end{array}$ & $\begin{array}{l}2.33 \\
(1.00-6.15)\end{array}$ & $\begin{array}{l}2.15 \\
(0.7 I-7.50)\end{array}$ & $\begin{array}{l}1.47 \\
(1.05-2.26)\end{array}$ & $\begin{array}{l}1.42 \\
(1.00-2.16)\end{array}$ & $\begin{array}{l}1.02 \\
(0.62-1.78)\end{array}$ & AF_CRT & $\begin{array}{l}1.07 \\
(0.59-2.01)\end{array}$ \\
\hline & & & & & & & & HF_CRT \\
\hline
\end{tabular}

Notes: Treatments are reported in the order of safety ranking. Comparisons between treatments should be read from left to right, and the estimate is in the cell in common between the row-defining treatment and the column-defining treatment. Statistically significant results are in bold.

Abbreviations: RR, risk ratio; Crl, credible interval; CF, conventional fractionation radiotherapy; CF_CRT, conventional fractionation chemoradiotherapy; HF, hyperfractionated radiotherapy; HF_CRT, hyperfractionated chemoradiotherapy; AF, accelerated fractionation radiotherapy; $A F \_C R T$, accelerated fractionation chemoradiotherapy; HART, accelerated hyperfractionated radiotherapy; HACRT, accelerated hyperfractionated chemoradiotherapy.

On the one hand, this measure is not biased by the outcome definition and assessment. On the other hand, it can comprehensively synthesize and cover nearly all deaths caused either by toxicity or by disease progression.

A mixed treatment comparison meta-analysis proved that among locoregional treatment, radiotherapy, chemotherapy, concomitant chemoradiotherapy, altered fractionation radiotherapy and altered fractionation concomitant chemoradiotherapy, the last one leads to the highest probability of survival in patients with nonmetastatic HNCs: $98 \%$ in a fixed effects model and $\geq 94 \%$ in a random effects model. ${ }^{33}$
Based on this study, we synthetically explored and compared each altered fractionation radiotherapy strategy or its combination with chemotherapy for the first time. Our results showed that each altered fractionation radiotherapy strategy was superior to conventional radiotherapy, which is consistent with the conclusions of previous research. ${ }^{32}$

In addition, the most important finding from our analysis was that HACRT was significantly more effective than all the other treatments. However, it may have been partially responsible for directing head and neck oncologists away from the altered fractionation radiotherapy, ${ }^{34}$ whereas clinicians have

Table 4 Late skin toxicity and late mucosal toxicity of treatments for head and neck cancer (RR [95\% Crl])

\begin{tabular}{|c|c|c|c|c|c|c|c|}
\hline & \multicolumn{7}{|c|}{ Late mucosal toxicity } \\
\hline \multirow[t]{7}{*}{$\begin{array}{l}\text { Late skin } \\
\text { toxicity }\end{array}$} & $\mathrm{CF}$ & $\begin{array}{l}1.01 \\
(0.22-5.02)\end{array}$ & $\begin{array}{l}2.53 \\
(0.84-9.50)\end{array}$ & $\begin{array}{l}0.69 \\
(0.45-1.04)\end{array}$ & $\begin{array}{l}0.47 \\
(0.16-1.29)\end{array}$ & $\begin{array}{l}1.54 \\
(0.46-5.13)\end{array}$ & $\begin{array}{l}0.63 \\
(0.43-0.86)\end{array}$ \\
\hline & $\begin{array}{l}0.68 \\
(0.08-4.22)\end{array}$ & HART & $\begin{array}{l}2.56 \\
(0.36-19.0)\end{array}$ & $\begin{array}{l}0.67 \\
(0.13-3.31)\end{array}$ & $\begin{array}{l}0.47 \\
(0.09-2.04)\end{array}$ & $\begin{array}{l}1.54 \\
(0.35-5.97)\end{array}$ & $\begin{array}{l}0.62 \\
(0.12-2.91)\end{array}$ \\
\hline & $\begin{array}{l}0.82 \\
(0.21-2.86)\end{array}$ & $\begin{array}{l}1.22 \\
(0.15-13.08)\end{array}$ & HF_CRT & $\begin{array}{l}0.27 \\
(0.08-0.75)\end{array}$ & $\begin{array}{l}0.19 \\
(0.03-0.81)\end{array}$ & $\begin{array}{l}0.60 \\
(0.10-3.05)\end{array}$ & $\begin{array}{l}0.25 \\
(0.06-074)\end{array}$ \\
\hline & $\begin{array}{l}0.85 \\
(0.49-\mid .4 I)\end{array}$ & $\begin{array}{l}1.24 \\
(0.19-11.03)\end{array}$ & $\begin{array}{l}1.02 \\
(0.32-3.55)\end{array}$ & $\mathrm{HF}$ & $\begin{array}{l}0.69 \\
(0.23-1.99)\end{array}$ & $\begin{array}{l}2.25 \\
(0.64-7.80)\end{array}$ & $\begin{array}{l}0.93 \\
(0.58-1.37)\end{array}$ \\
\hline & $\begin{array}{l}1.16 \\
(0.25-4.43)\end{array}$ & $\begin{array}{l}1.69 \\
(0.23-15.99)\end{array}$ & $\begin{array}{l}1.36 \\
(0.21-9.49)\end{array}$ & $\begin{array}{l}1.37 \\
(0.28-5.82)\end{array}$ & AF_CRT & $\begin{array}{l}3.26 \\
(1.38-8.31)\end{array}$ & $\begin{array}{l}1.34 \\
(0.49-3.73)\end{array}$ \\
\hline & $\begin{array}{l}1.23 \\
(0.56-2.57)\end{array}$ & $\begin{array}{l}1.81 \\
(0.35-13.12)\end{array}$ & $\begin{array}{l}1.47 \\
(0.35-6.88)\end{array}$ & $\begin{array}{l}I .45 \\
(0.59-3.5 I)\end{array}$ & $\begin{array}{l}1.07 \\
(0.34-3.78)\end{array}$ & CF_CRT & $\begin{array}{l}0.41 \\
(0.12-1.33)\end{array}$ \\
\hline & $\begin{array}{l}1.32 \\
(0.90-1.96)\end{array}$ & $\begin{array}{l}1.93 \\
(0.31-16.60)\end{array}$ & $\begin{array}{l}1.61 \\
(0.46-6.38)\end{array}$ & $\begin{array}{l}1.56 \\
(0.93-2.74)\end{array}$ & $\begin{array}{l}1.15 \\
(0.30-5.27)\end{array}$ & $\begin{array}{l}1.08 \\
(0.52-2.38)\end{array}$ & $\mathrm{AF}$ \\
\hline
\end{tabular}

Notes: Treatments are reported in the order of safety ranking. Comparisons between treatments should be read from left to right, and the estimate is in the cell in common between the row-defining treatment and the column-defining treatment. Statistically significant results are in bold.

Abbreviations: RR, risk ratio; Crl, credible interval; CF, conventional fractionation radiotherapy; CF_CRT, conventional fractionation chemoradiotherapy; HF, hyperfractionated radiotherapy; HF_CRT, hyperfractionated chemoradiotherapy; AF, accelerated fractionation radiotherapy; AF_CRT, accelerated fractionation chemoradiotherapy; HART, accelerated hyperfractionated radiotherapy. 


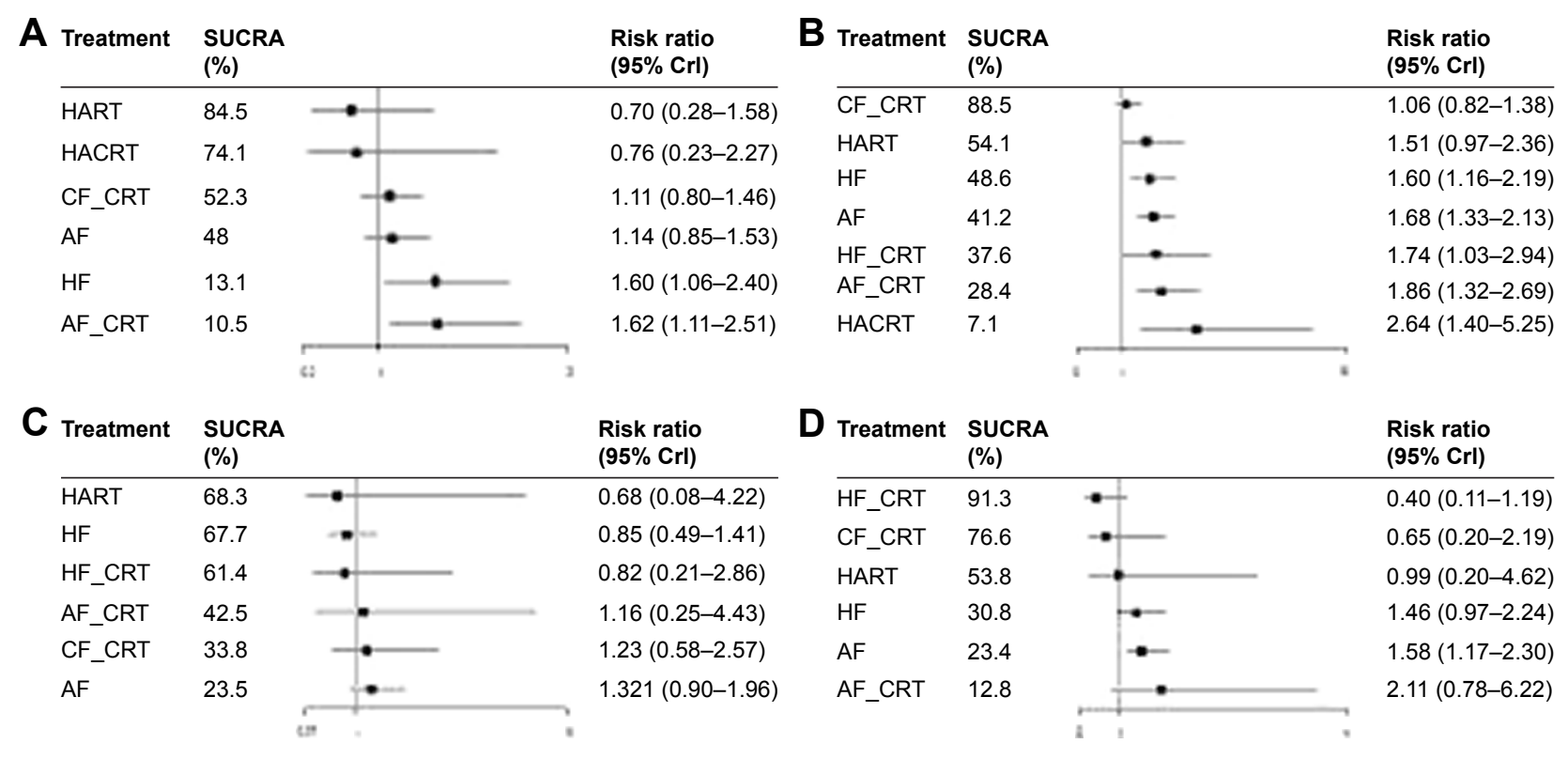

Figure 4 Forest plots of safety of different treatments compared to conventional fractionation radiotherapy: (A) acute skin toxicity; (B) acute mucosal toxicity; (C) late skin toxicity; and (D) late mucosal toxicity.

Abbreviations: Crl, credible interval; CF_CRT, conventional fractionation chemoradiotherapy; HF, hyperfractionated radiotherapy; HF_CRT, hyperfractionated chemoradiotherapy; AF, accelerated fractionation radiotherapy; AF_CRT, accelerated fractionation chemoradiotherapy; HART, accelerated hyperfractionated radiotherapy; HACRT, accelerated hyperfractionated chemoradiotherapy; SUCRA, surface under the cumulative ranking curve.

readily adopted $\mathrm{CF}_{-} \mathrm{CRT}^{35}$ as the contemporary standard of care in the radiotherapeutic management of locoregionally advanced HNCs. Most underdeveloped and developing countries (where HNC is a major burden) are lacking the radiotherapy infrastructure (equipment and human resources); therefore, patients must wait a long time for radiotherapy services.

Compared with traditional pairwise meta-analyses, NMA can present a comprehensive and transparent picture of hierarchies of combined direct and indirect evidence for all relative treatment effects and provide estimates with maximum power. ${ }^{36-39}$ A pairwise meta-analysis directly comparing the efficacy of CF_CRT with altered fractionation radiotherapy alone in locoregionally advanced head and neck squamous cell carcinoma significantly favored CF_CRT for OS (HR: 0.73, 95\% CI: 0.62-0.86), DFS (HR: 0.79, 95\% CI: 0.68-0.92) and LRC (HR: 0.71, 95\% CI: 0.59-0.84), and there were no significant differences in the incidence of severe acute toxicity (dermatitis and mucosa). ${ }^{40}$ However, the results of an adjusted indirect overall comparison metaanalysis suggested no significant difference between them in $\mathrm{OS},{ }^{41}$ which is in accordance with our NMA results. There were no significant differences between CF_CRT and other altered fractionation radiotherapy treatments in OS and DFS. CF_CRT, which had the lowest SUCRA value, exhibited the worst local control effect compared to the other treatments, but it showed the lowest risk of acute mucosal toxicity in its
SUCRA ranking. In a meta-analysis, an OS benefit was also noted for patients treated with HF than with AF. ${ }^{31}$ However, no significant differences were found.

In general, unconventional radiotherapy combined with chemotherapy has a better effect than unconventional radiotherapy alone, accompanied by the increased risk of acute toxicity; however, late toxicity was not significantly different. According to the recent evidence on both chemotherapy and radiotherapy, these schedules of altered fractionation radiotherapy are feasible and tolerable combined with concurrent chemotherapy.

The SUCRA results indicated that HACRT was the treatment with the best ranking in all three efficacy indexes but had a relatively acceptable risk of safety, which clinicians could adopt for curative treatment strategies through which patients may live for decades and be confident in its safety. Improvements in the understanding of tumor biology and advancement in radiotherapy planning and delivery may further enhance the utilization of altered fractionation radiotherapy.

This study is the most complete NMA to assess altered fractionation radiotherapy or its combination with chemotherapy in HNC compared with many treatments, which appeared to offer clearer results on their efficacy and safety. Furthermore, a comprehensive search strategy, strict selection criteria and a large amount of data (72 included studies with 21,868 patients) increased the reliability of 
this analysis. However, there are several implicit limitations to our NMA. First, a few eligible studies reported data beyond 5 years with a limited follow-up period. The longterm relative efficacy and safety of these treatments have not been investigated in depth. Second, part of the included literature does not provide the corresponding outcome indicators directly. There will be some deviation in extracting the corresponding data from the survival curve. Third, the kind and dose of chemotherapy drugs and the timing of combination with chemotherapy (adjuvant, induction, alternating or concomitant) were not considered. There was a certain degree of difference between different drugs and the timing of chemotherapy in efficacy and safety, which may have a certain impact on our results. Fourth, we classified hybrid accelerated hyperfractionated, split- or late-course accelerated hyperfractionated and consecutive accelerated hyperfractionated as HART treatment. In future research, further advanced measures are compulsory for obtaining more accurate and appropriate results. Fifth, the results might be applied only to countries that have a welldeveloped medical infrastructure and an easily accessible healthcare system. Sixth, language restrictions on inclusion of the literature will lead to language selection bias. Exclusion of non-English studies may exclude studies that found a null effect and thus overestimate effectiveness.

\section{Conclusion}

Our study presents a comprehensive and transparent picture of hierarchies of the efficacy and safety of altered fractionation radiotherapy with or without chemotherapy in the treatment of HNCs. The results of Bayesian analysis supported the role of HACRT as the preferable treatment modality for HNCs with high OS, DFS and LRC. However, its acute mucosal toxicity is relatively significant. Therefore, cautious and individualized treatment decisions are encouraged.

\section{Acknowledgments}

This work was supported in part by the grants from Postgraduate Innovation Research Project in Jilin University (No 2017097) and Norman Bethne Program of Jilin University (No 2015225 and 2015203).

\section{Disclosure}

The authors report no conflicts of interest in this work.

\section{References}

1. Siegel RL, Miller KD, Jemal A. Cancer statistics, 2016. CA Cancer J Clin. 2016;66(1):7-30.
2. Stransky N, Egloff AM, Tward AD, et al. The mutational landscape of head and neck squamous cell carcinoma. Science. 2011;333(6046): $1157-1160$.

3. Ferlay J, Bray F, Pisani P, Parkin DM. GLOBOCAN 2002: Cancer Incidence. Mortality and Prevalence Worldwide, Version 2.0. Lyon: IARC Press; 2004.

4. Wei WI. Commentary: Head and neck carcinomas in the developing world. BMJ. 2002;325(7368):827.

5. Madhavan R, Bhaskar PK, Nithiya AM. A comparative study of radical radiotherapy with weekly paclitaxel versus radical radiotherapy with weekly cisplatin in the management of locally advanced squamous cell carcinomas of head and neck. IJRMS. 2017;5(2):473.

6. Bernier J, Hall EJ, Giaccia A. Radiation oncology: a century of achievements. Nature Reviews Cancer. 2004;4(9):737-747.

7. Coutard $\mathrm{H}$. The results and methods of treatment of cancer by radiation. Ann Surg. 1937;106(4):584-598.

8. Ling CC, Gerweck LE, Zaider M, Yorke E. Dose-rate effects in external beam radiotherapy redux. Radiother Oncol. 2010;95(3): 261-268.

9. Mallick S, Benson R, Julka PK, Rath GK. Altered fractionation radiotherapy in head and neck squamous cell carcinoma. J Egypt Natl Canc Inst. 2016;28(2):73-80.

10. Ahmed KA, Correa CR, Dilling TJ, et al. Altered fractionation schedules in radiation treatment: a review. Semin Oncol. 2014;41(6): 730-750.

11. Horiot JC, Le Fur R, N'Guyen T, et al. Hyperfractionation versus conventional fractionation in oropharyngeal carcinoma: final analysis of a randomized trial of the EORTC cooperative group of radiotherapy. Radiother Oncol. 1992;25(4):231-241.

12. Fu KK, Pajak TF, Trotti A, et al. A Radiation Therapy Oncology Group (RTOG) phase III randomized study to compare hyperfractionation and two variants of accelerated fractionation to standard fractionation radiotherapy for head and neck squamous cell carcinomas: first report of RTOG 9003. Int J Radiat Oncol Biol Phys. 2000;48(1): $7-16$.

13. Pinto LH, Canary PC, Araújo CM, Bacelar SC, Souhami L. Prospective randomized trial comparing hyperfractionated versus conventional radiotherapy in stages III and IV oropharyngeal carcinoma. Int J Radiat Oncol Biol Phys. 1991;21(3):557-562.

14. Cummings B, Keane T, Pintilie M, et al. Five year results of a randomized trial comparing hyperfractionated to conventional radiotherapy over four weeks in locally advanced head and neck cancer. Radiother Oncol. 2007;85(1):7-16.

15. Saunders MI, Rojas AM, Parmar MK, Dische S, CHART Trial Collaborators. Mature results of a randomized trial of accelerated hyperfractionated versus conventional radiotherapy in head-and-neck cancer. Int J Radiat Oncol Biol Phys. 2010;77(1):3-8.

16. Bourhis J, Lapeyre M, Tortochaux J, et al. Phase III randomized trial of very accelerated radiation therapy compared with conventional radiation therapy in squamous cell head and neck cancer: a GORTEC trial. J Clin Oncol. 2006;24(18):2873-2878.

17. Poulsen MG, Denham JW, Peters LJ, et al. A randomised trial of accelerated and conventional radiotherapy for stage III and IV squamous carcinoma of the head and neck: a Trans-Tasman Radiation Oncology Group Study. Radiother Oncol. 2001;60(2):113-122.

18. Yeoh EE, Holloway RH, Fraser RJ, et al. Hypofractionated versus conventionally fractionated radiation therapy for prostate carcinoma: updated results of a phase III randomized trial. Int J Radiat Oncol Biol Phys. 2006;66(4):1072-1083.

19. Budach W, Hehr T, Budach V, Belka C, Dietz K. A meta-analysis of hyperfractionated and accelerated radiotherapy and combined chemotherapy and radiotherapy regimens in unresected locally advanced squamous cell carcinoma of the head and neck. BMC Cancer. 2006;6:28.

20. Fallai C, Bolner A, Signor M, et al. Long-term results of conventional radiotherapy versus accelerated hyperfractionated radiotherapy versus concomitant radiotherapy and chemotherapy in locoregionally advanced carcinoma of the oropharynx. Tumori. 2006;92(1):41-54. 
21. Welz H, Pöttgen C, Abu Jawad J, et al. Hyperfractionated accelerated radiotherapy versus conventional fractionation both combined with chemotherapy in patients with locally advanced head and neck carcinomas: a retrospective analysis of a monoinstitutional series. Oncology. 2009;76(6):405-412.

22. Parvanova V, Gesheva N, Klenova A, et al. Hypofractionation radiotherapy versus combined conventional radio-chemotherapy in advanced head and neck tumors. Radiother Oncol. 2007;82(2): S59-S60.

23. Lacas B, Bourhis J, Overgaard J, et al. Role of radiotherapy fractionation in head and neck cancers (MARCH): an updated meta-analysis. Lancet Oncol. 2017;18(9):1221-1237.

24. Cox JD, Stetz J, Pajak TF. Toxicity criteria of the Radiation Therapy Oncology Group (RTOG) and the European Organization for Research and Treatment of Cancer (EORTC). Int J Radiat Oncol Biol Phys. 1995; 31(5):1341-1346.

25. Miller AB, Hoogstraten B, Staquet M, Winkler A. Reporting results of cancer treatment. Cancer. 1981;47(1):207-214.

26. Parmar MK, Torri V, Stewart L. Extracting summary statistics to perform meta-analyses of the published literature for survival endpoints. Stat Med. 1998;17(24):2815-2834.

27. Tierney JF, Stewart LA, Ghersi D, Burdett S, Sydes MR. Practical methods for incorporating summary time-to-event data into meta-analysis. Trials. 2007;8:16.

28. Higgins JP, Green S. Cochrane handbook for systematic reviews of interventions version 5.0.0. Cochrane Database Syst Rev. 2011; 2009(2):S38.

29. Pignon JP, Bourhis J, Domenge C, Designé L. Chemotherapy added to locoregional treatment for head and neck squamous-cell carcinoma: three meta-analyses of updated individual data. Lancet. 2000; 355(9208):949-955.

30. Pignon JP, Le Maître A, Maillard E, Bourhis J; MACH-NC Collaborative Group. Meta-analysis of chemotherapy in head and neck cancer (MACH-NC): an update on 93 randomised trials and 17,346 patients. Radiother Oncol. 2009;92(1):4-14.

31. Bourhis J, Overgaard J, Audry H, et al. Hyperfractionated or accelerated radiotherapy in head and neck cancer: a meta-analysis. Lancet. 2006;368(9538):843-854.
32. Baujat B, Bourhis J, Blanchard P, et al. Hyperfractionated or Accelerated Radiotherapy for Head and Neck Cancer. Cochrane Database of Systematic Reviews. 2010;12:CD002026.

33. Blanchard P, Hill C, Guihenneuc-Jouyaux C, et al. Mixed treatment comparison meta-analysis of altered fractionated radiotherapy and chemotherapy in head and neck cancer. J Clin Epidemiol. 2011;64(9): 985-992.

34. Dische S, Saunders M, Barrett A, Harvey A, Gibson D, Parmar M. A randomised multicentre trial of CHART versus conventional radiotherapy in head and neck cancer. Radiother Oncol. 1997;44(2):123-136.

35. Grégoire V, Lefebvre JL, Licitra L, Felip E; EHNS-ESMO-ESTRO Guidelines Working Group. Squamous cell carcinoma of the head and neck: EHNS-ESMO-ESTRO Clinical Practice Guidelines for diagnosis, treatment and follow-up. Ann Oncol. 2010;21(Suppl 5):v184-v186.

36. Lu G, Ades AE. Combination of direct and indirect evidence in mixed treatment comparisons. Stat Med. 2004;23(20):3105-3124.

37. Salanti G, Higgins JP, Ades AE, Ioannidis JP. Evaluation of networks of randomized trials. Stat Methods Med Res. 2008;17(3):279-301.

38. Higgins JP, Whitehead A. Borrowing strength from external trials in a meta-analysis. Stat Med. 1996;15(24):2733-2749.

39. Salanti G, Ades AE, Ioannidis JP. Graphical methods and numerical summaries for presenting results from multiple-treatment meta-analysis: an overview and tutorial. J Clin Epidemiol. 2011;64(2):163-171.

40. Gupta T, Kannan S, Ghosh-Laskar S, Agarwal JP, Review S. Systematic review and meta-analysis of conventionally fractionated concurrent chemoradiotherapy versus altered fractionation radiotherapy alone in the definitive management of locoregionally advanced head and neck squamous cell carcinoma. Clin Oncol. 2016;28(1):50-61.

41. Gupta T, Kannan S, Ghosh-Laskar S, Agarwal JP. Concomitant chemoradiotherapy versus altered fractionation radiotherapy in the radiotherapeutic management of locoregionally advanced head and neck squamous cell carcinoma: an adjusted indirect comparison metaanalysis. Head Neck. 2015;37(5):670-676. 


\section{Supplementary materials \\ Search strategies \\ PubMed \\ \#1}

((“'Head and Neck Neoplasms”[Mesh])) OR (()((()((()((()((()((() (Head[Title/Abstract] AND Neck Neoplasms[Title/Abstract])) OR (Neoplasms, Head[Title/Abstract] AND Neck[Title/ Abstract])) OR Head, Neck Neoplasms[Title/Abstract]) OR (Cancer of Head[Title/Abstract] AND Neck[Title/Abstract])) OR (Head[Title/Abstract] AND Neck Cancer[Title/ Abstract])) OR (Cancer of the Head[Title/Abstract] AND Neck[Title/Abstract])) OR Upper Aerodigestive Tract Neoplasms[Title/Abstract]) OR UADT Neoplasms[Title/ Abstract]) OR Neoplasm, UADT[Title/Abstract]) OR Neoplasms, UADT[Title/Abstract]) OR UADT Neoplasm[Title/ Abstract]) OR Neoplasms, Upper Aerodigestive Tract[Title/ Abstract]) OR Head Neoplasms[Title/Abstract]) OR Neoplasms, Head[Title/Abstract]) OR Neck Neoplasms[Title/ Abstract]) OR Neoplasms, Neck[Title/Abstract]) OR Cancer of Head[Title/Abstract]) OR Head Cancer[Title/Abstract]) OR Cancer of the Head[Title/Abstract]) OR Cancer of Neck[Title/ Abstract]) OR Neck Cancer[Title/Abstract]) OR Cancer of the Neck[Title/Abstract])

\#2

((((cancer*[Title/Abstract]) OR neoplas*[Title/Abstract]) OR tumor*[Title/Abstract]) OR tumour*[Title/Abstract]) OR carcinom*[Title/Abstract]

\#3

(((((()head[Title/Abstract]) OR neck[Title/Abstract]) OR larynx[Title/Abstract]) OR pharnyx[Title/Abstract]) OR oropharyn*[Title/Abstract]) OR hypopharyn*[Title/ Abstract]) OR laryn*[Title/Abstract]) OR oral cavity[Title/ Abstract]

\#4

$\# 2$ and \#3

\#5

\#1 or \#4

\#6

((hyperfraction*[Title/Abstract]) OR accelerat*[Title/ Abstract]) OR fractionat*[Title/Abstract]

\#7

(Randomized Controlled Trial[Publication Type]) OR random*

\#8

$\# 5$ and $\# 6$ and $\# 7$

\section{Embase}

\#1

'head and neck tumor'/exp

\#2

cancer* OR neoplas* OR tumor* OR tumour* OR carcinom*:ti,ab

\#3

'head'/exp OR head OR 'neck'/exp OR neck OR 'larynx'/ exp OR larynx OR pharnyx OR oropharyn* OR hypopharyn* OR laryn* OR oral AND cavity:ti,ab

\#4

\#2 AND \#3

\#5

\#1 OR \#4

\#6

hyperfraction* OR accelerat* OR fractionat*:ti,ab

\#7

random*

\#8

\#5 AND \#6 AND \#7

\section{Cochrane Library}

\#1

MeSH descriptor: [Head and Neck Neoplasms] explode all trees

\#2

cancer*:ti,ab,kw or neoplas*:ti,ab,kw or tumor*:ti,ab,kw or tumour*:ti,ab,kw or carcinom*:ti,ab,kw (Word variations have been searched)

\#3

head:ti,ab,kw or neck:ti,ab,kw or larynx:ti,ab,kw or pharnyx: ti,ab,kw or oropharyn*:ti,ab,kw or hypopharyn*:ti,ab,kw or laryn*:ti,ab,kw or oral cavity:ti,ab,kw

(Word variations have been searched)

\#4

\#2 and \#3

\#5

$\# 1$ and \#4

\#6

hyperfraction*:ti,ab,kw or accelerat*:ti,ab,kw or fractionat*: ti,ab,kw (Word variations have been searched)

\#7

random* (Word variations have been searched)

\#8

\#5 and \#6 and \#7 


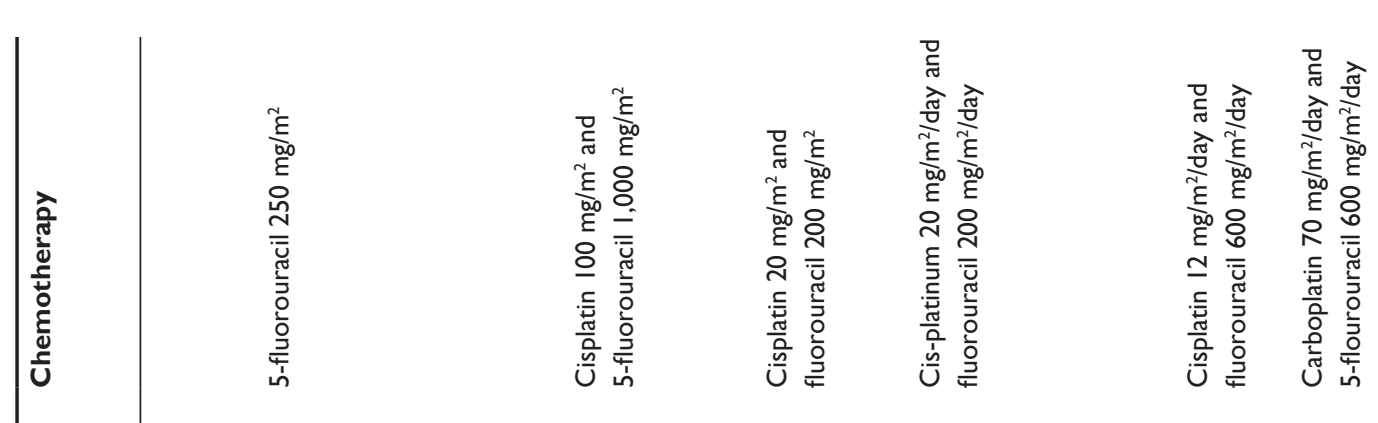

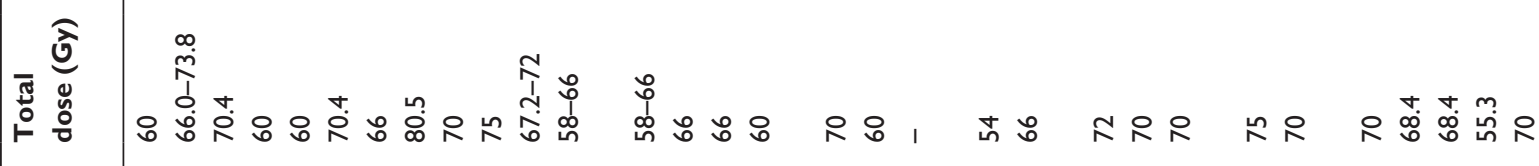

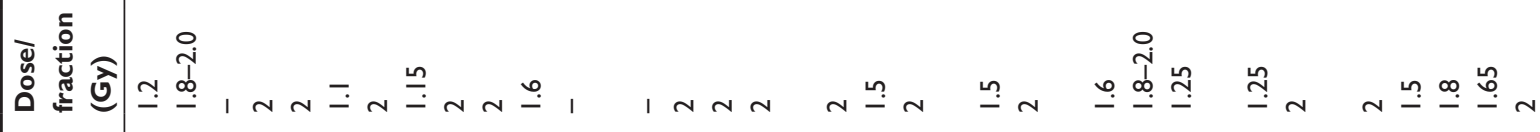

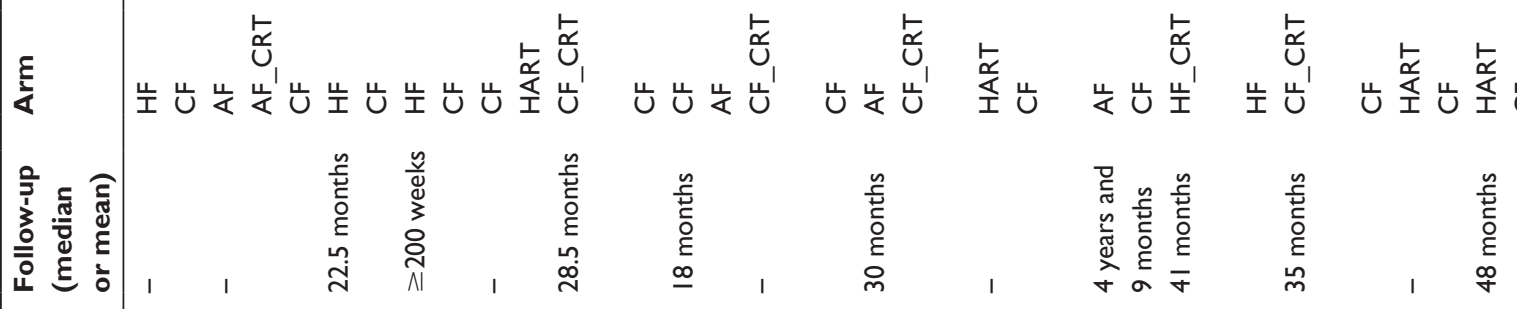

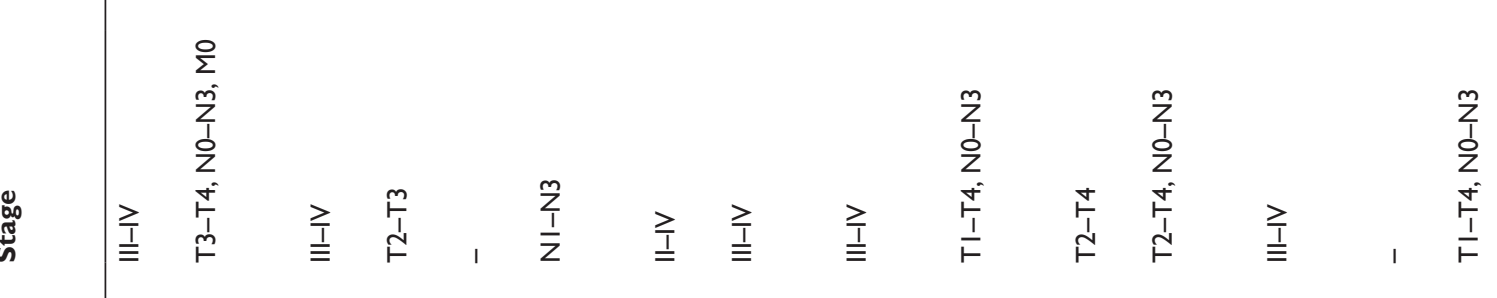

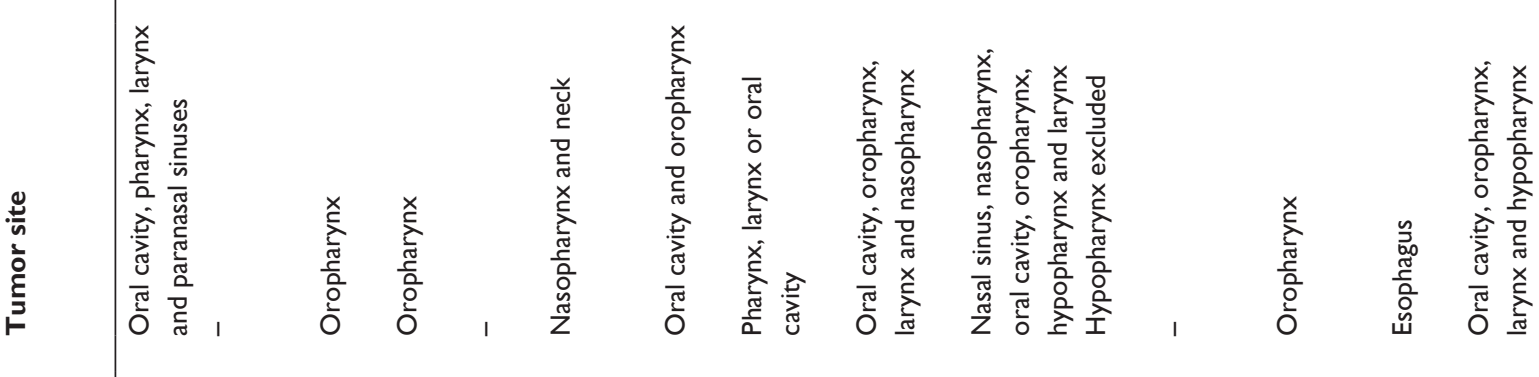

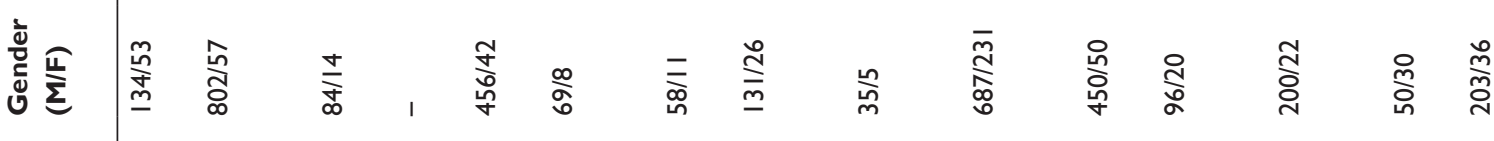

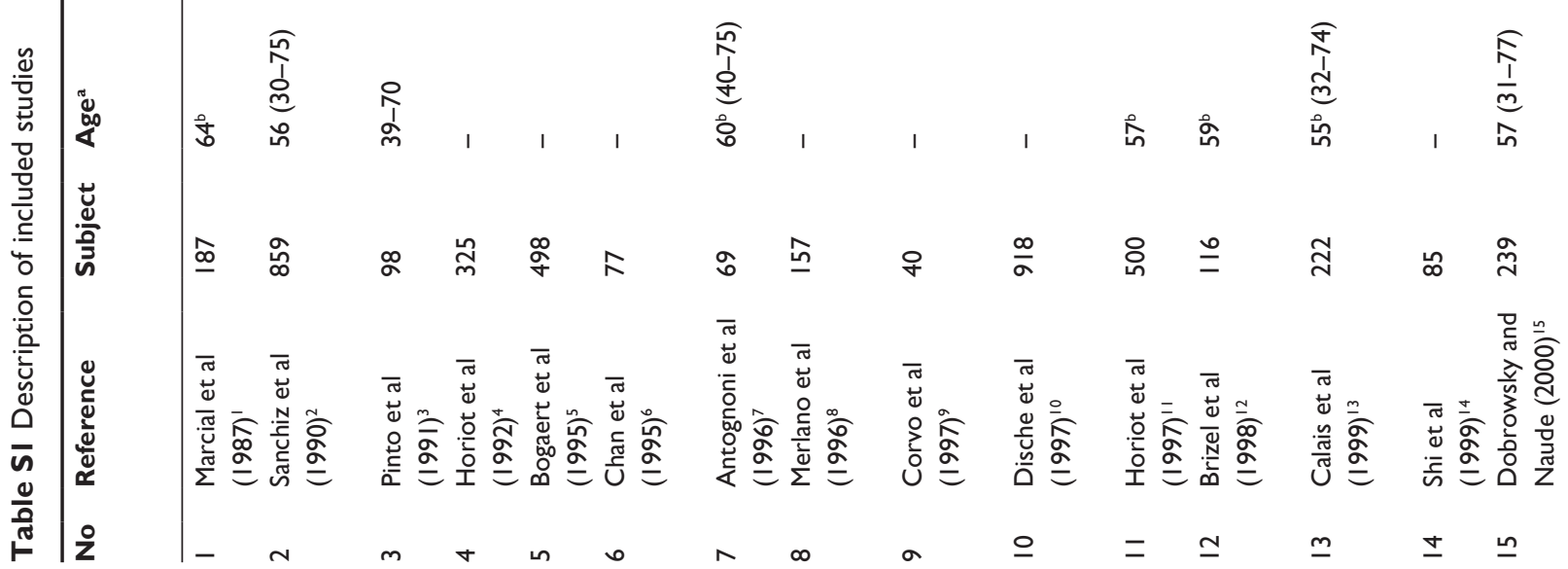




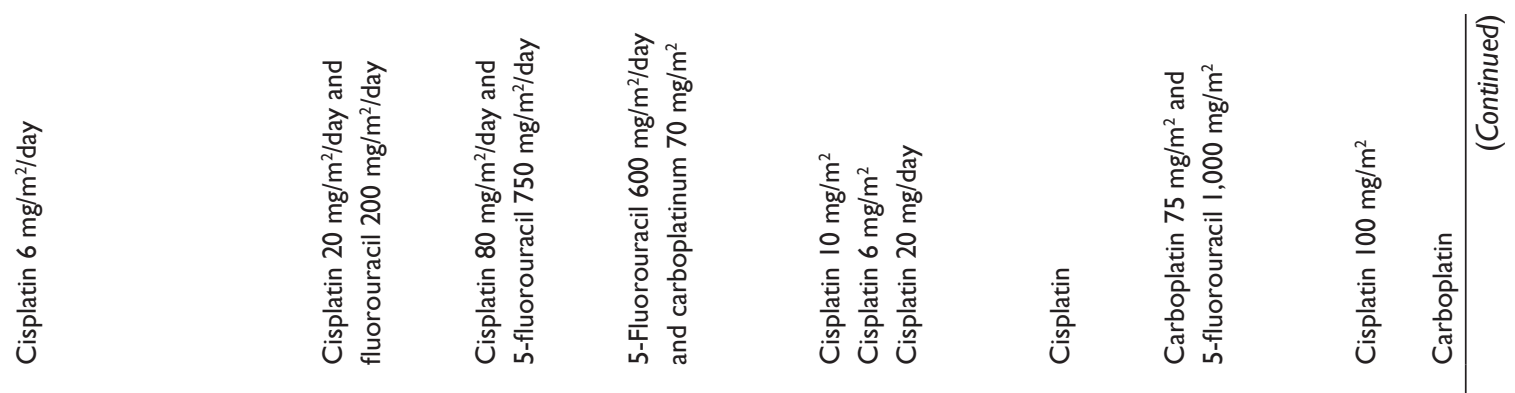

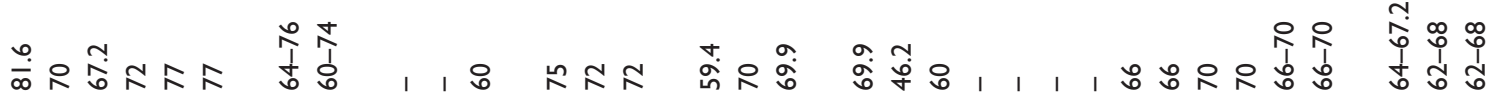

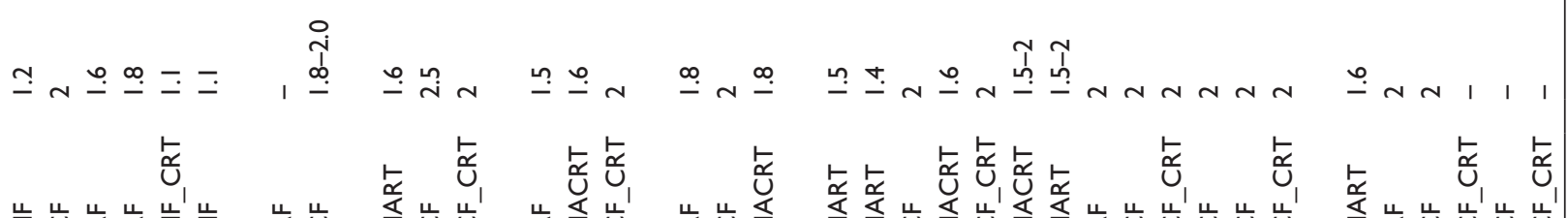

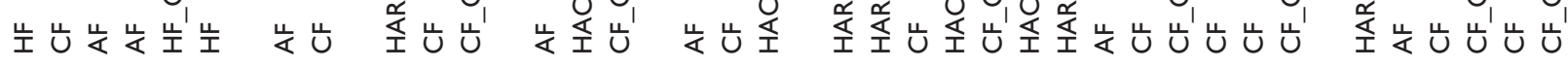

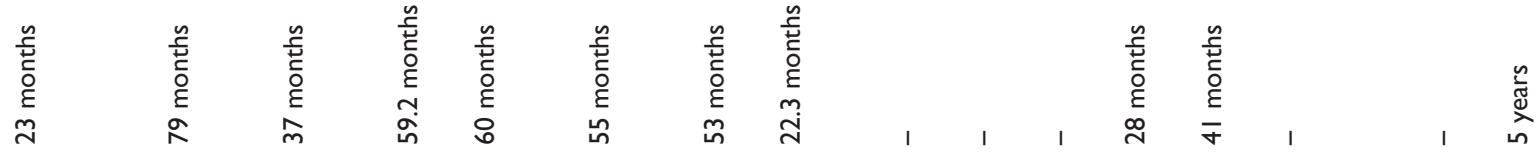

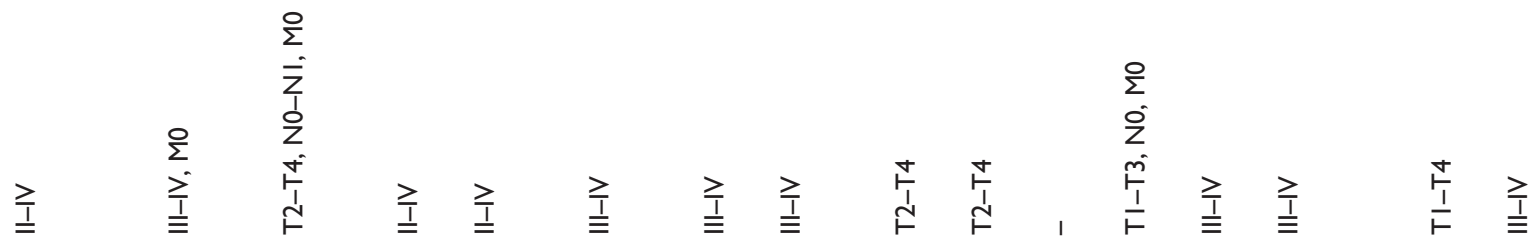

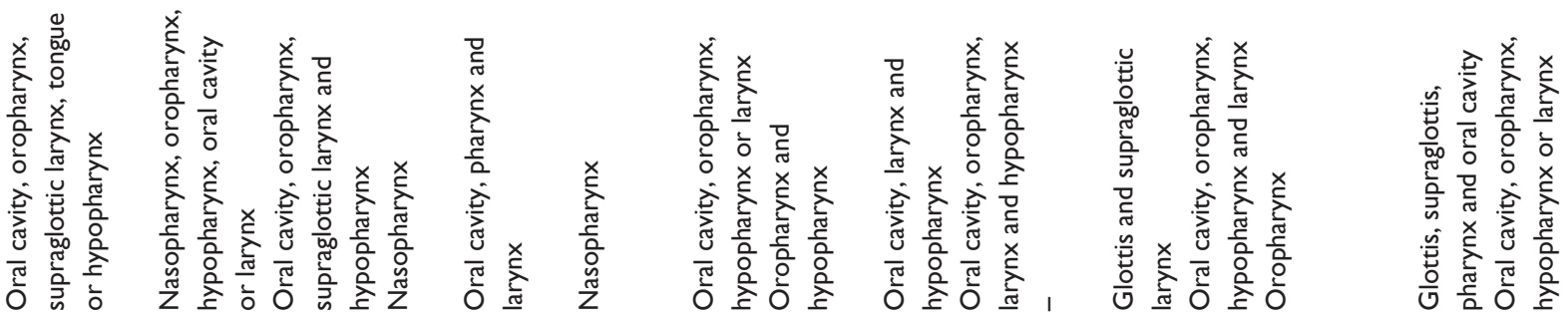

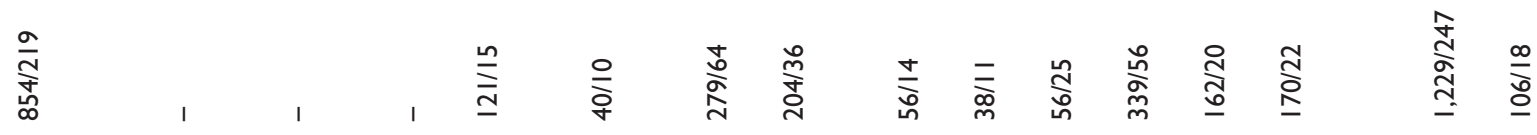

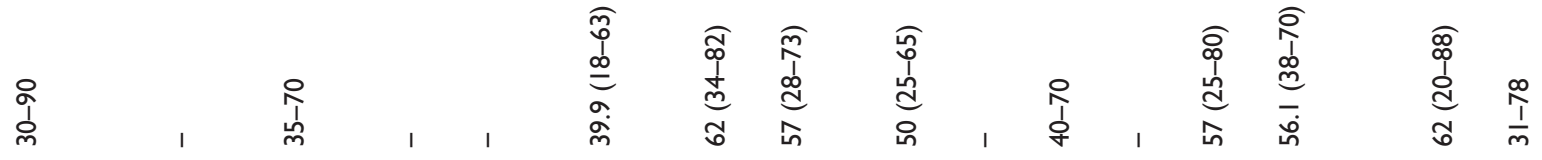

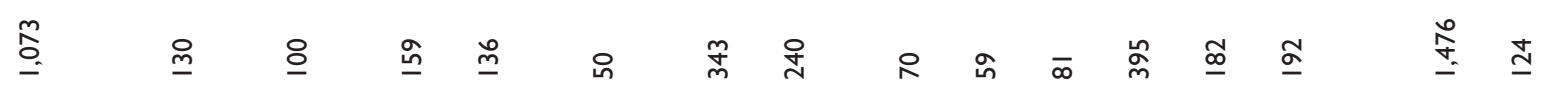

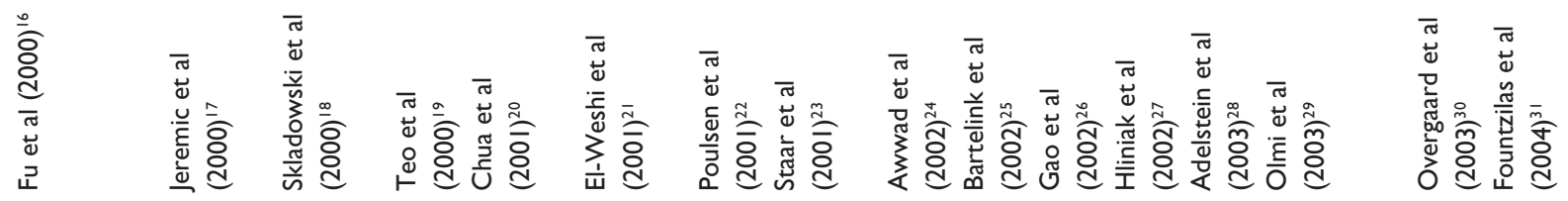

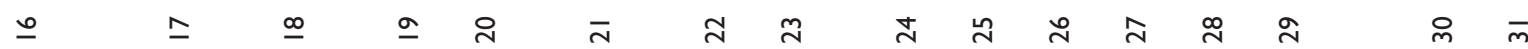




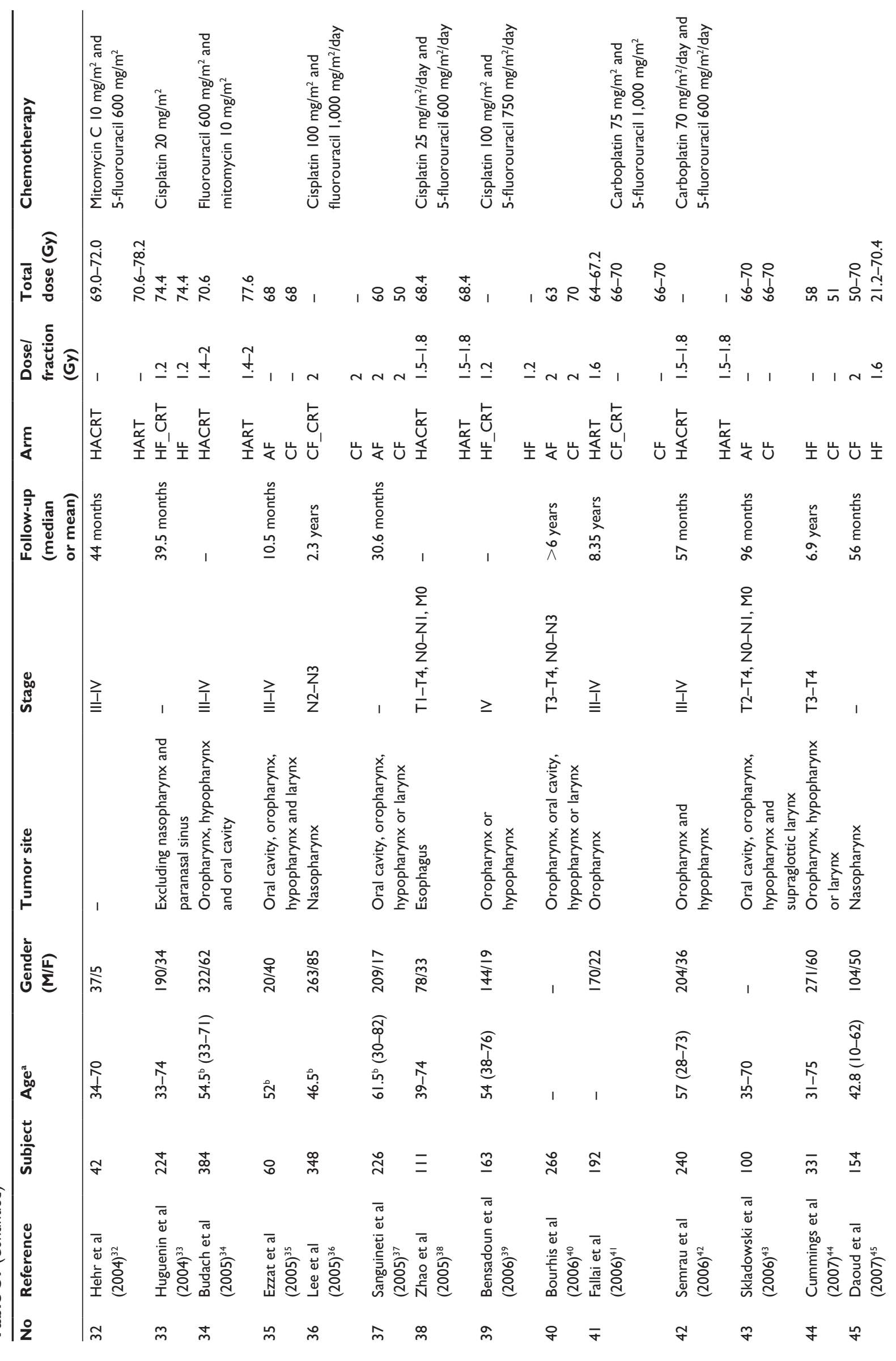



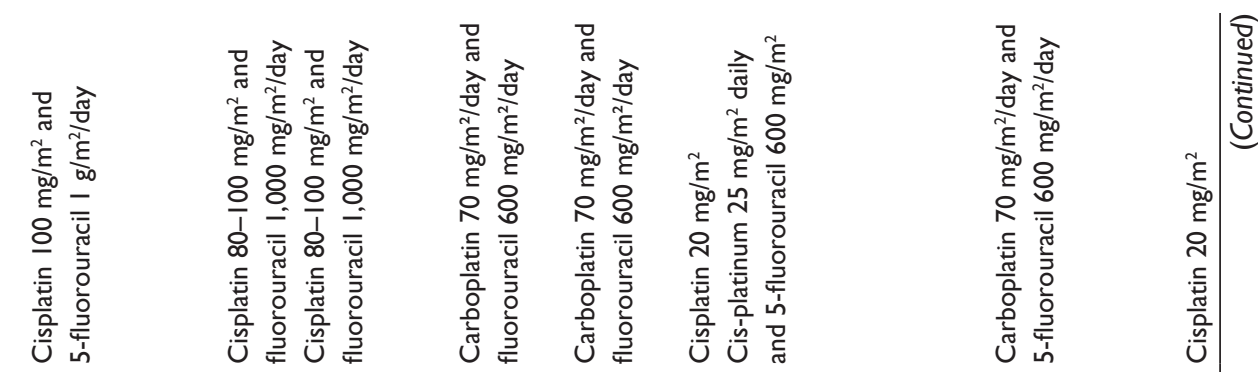

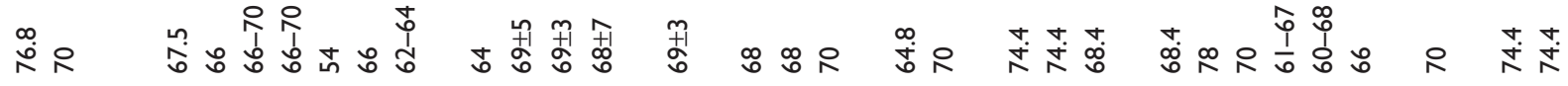

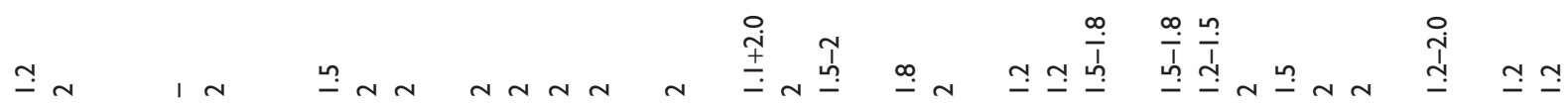

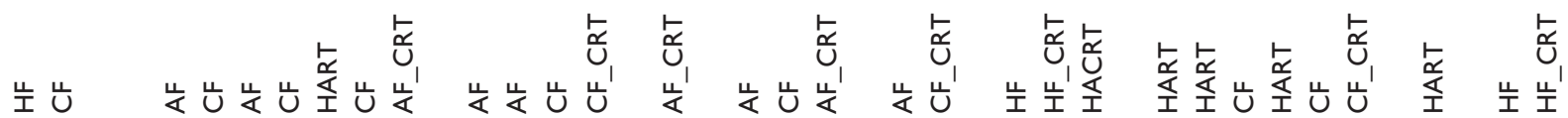

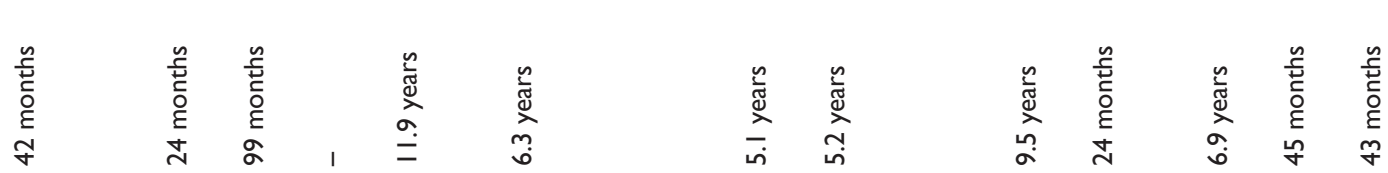

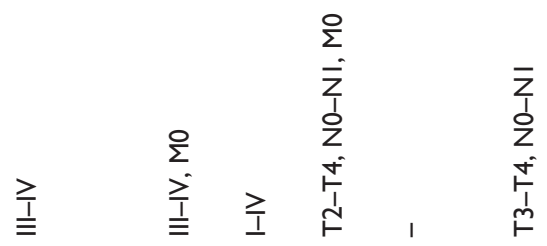
$\geq \quad \stackrel{?}{\equiv}$ $\stackrel{\gtrless}{=} \quad \mathbb{I}, \stackrel{\gtrless}{\equiv}$
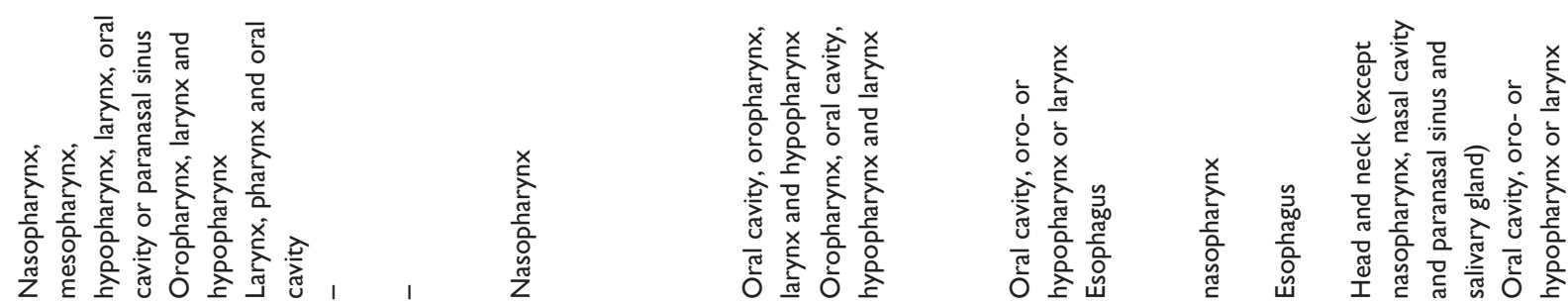

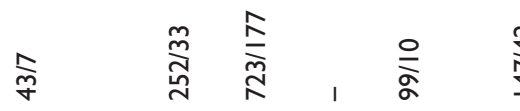

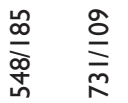

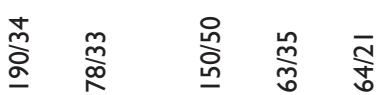

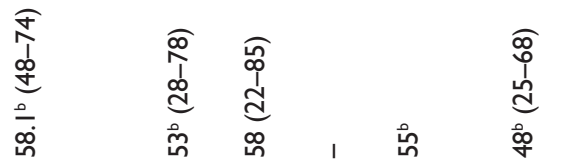

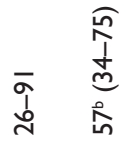

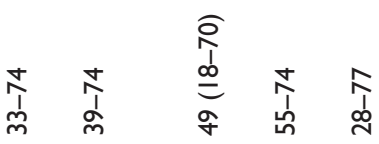

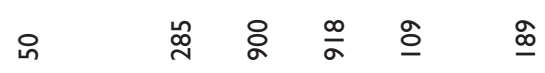

$m$

ปัป

$\stackrel{4}{4}$

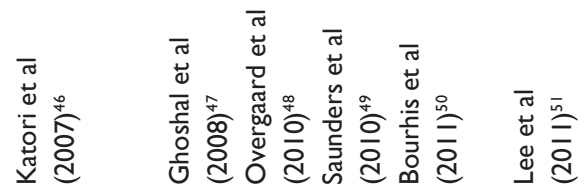

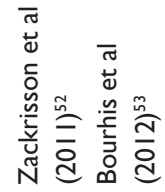

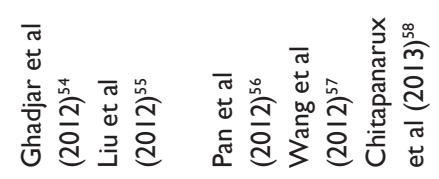

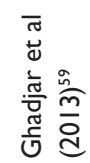
f

f $\stackrel{\infty}{f}$ i $\bar{n}$

กิ กิ

แั นn

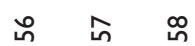

in 


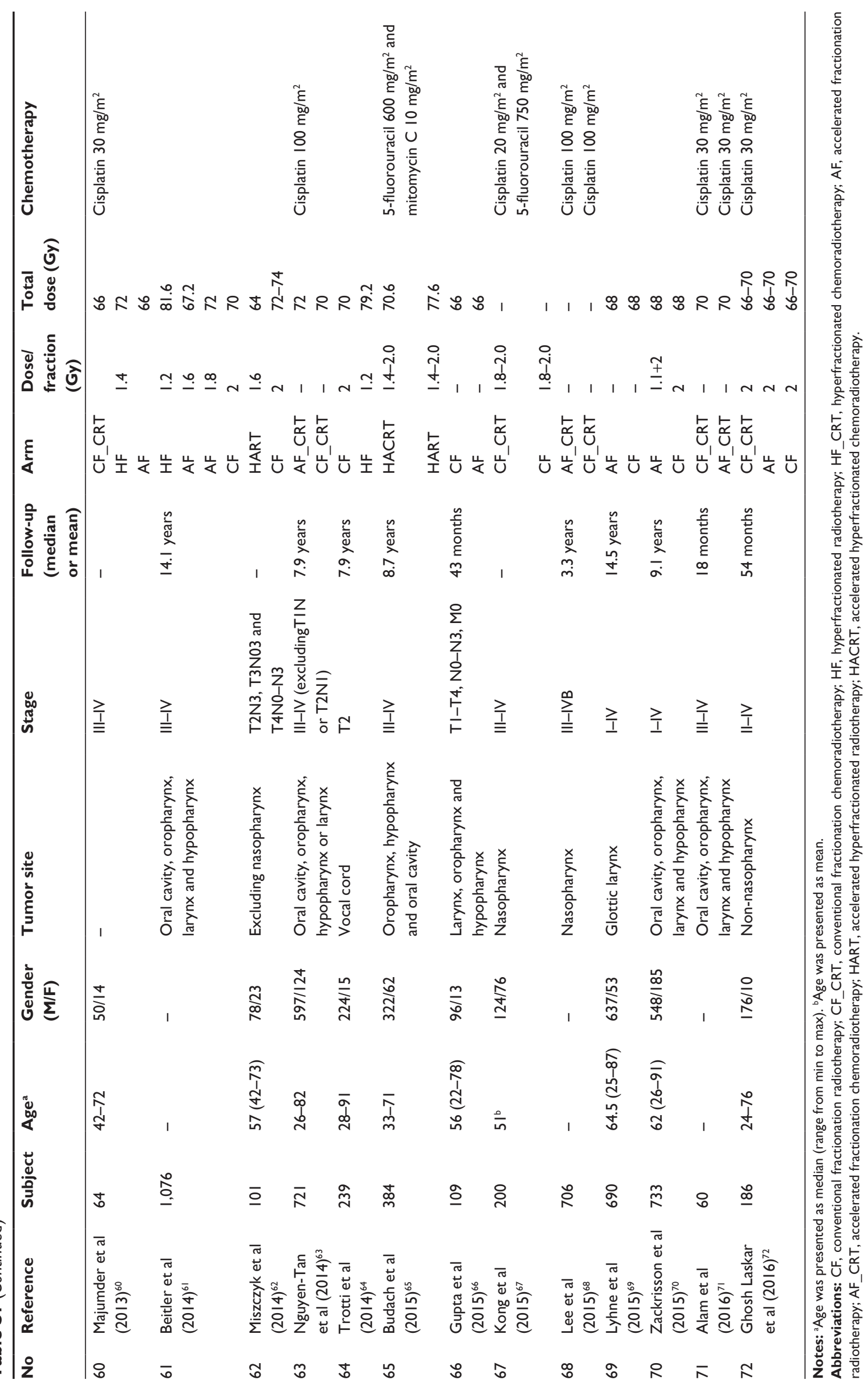




\section{References}

1. Marcial VA, Pajak TF, Chang C, Tupchong L, Stetz J. Hyperfractionated photon radiation therapy in the treatment of advanced squamous cell carcinoma of the oral cavity, pharynx, larynx, and sinuses, using radiation therapy as the only planned modality: (preliminary report) by the Radiation Therapy Oncology Group (RTOG). Int J Radiat Oncol Biol Phys. 1987;13(1):41-47.

2. Sanchiz F, Milla A, Torner J, et al. Single fraction per day versus two fractions per day versus radiochemotherapy in the treatment of head and neck cancer. Int J Radiat Oncol Biol Phys. 1990;19(6):1347-1350.

3. Pinto LHJ, Canary PCV, Araujo CMM, Bacelar SC, Souhami L. Prospective randomized trial comparing hyperfractionated versus conventional radiotherapy in stages III and IV oropharyngeal carcinoma. Int J Radiat Oncol Biol Phys. 1991;21(3):557-562.

4. Horiot JC, Fur R, N'Guyen T, et al. Hyperfractionation versus conventional fractionation in oropharyngeal carcinoma: final analysis of a randomized trial of the EORTC cooperative group of radiotherapy. Radiother Oncol J Eur Soc Ther Radiol Oncol. 1992;25(4):231-241. Available from: http://onlinelibrary.wiley.com/o/cochrane/clcentral/ articles/983/CN-00089983/frame.html

5. Bogaert W, Schueren E, Horiot JC, et al. The EORTC randomized trial on three fractions per day and misonidazole (trial no. 22811) in advanced head and neck cancer: long-term results and side effects. Radiother Oncol J Eur Soc Ther Radiol Oncol. 1995;35(2):91-99. Available from: http://onlinelibrary.wiley.com/o/cochrane/clcentral/ articles/578/CN-00118578/frame.html

6. Chan ATC, Teo PML, Leung TWT, et al. A prospective randomized study of chemotherapy adjunctive to definitive radiotherapy in advanced nasopharyngeal carcinoma. Int J Radiat Oncol Biol Phys. 1995;33(3):569-577.

7. Antognoni $\mathrm{P}$, Bignardi M, Cazzaniga F, et al. Accelerated radiation therapy for locally advanced squamous cell carcinomas of the oral cavity and oropharynx selected according to tumor cell kinetics - a phase II multicenter study. Int J Radiat Oncol Biol Phys. 1996;36(5):1137-1145.

8. Merlano M, Benasso M, Corvo R, et al. Five-year update of a randomized trial of alternating radiotherapy and chemotherapy compared with radiotherapy alone in treatment of unresectable squamous cell carcinoma of the head and neck. J Natl Cancer Inst. 1996;88(9):583-589.

9. Corvo R, Giaretti W, Sanguineti G, et al. Chemoradiotherapy as an alternative to radiotherapy alone in fast proliferating head and neck squamous cell carcinomas. Clin Cancer Res J Am Assoc Cancer Res. 1997;3(11): 1993-1997.

10. Dische S, Saunders M, Barrett A, Harvey A, Gibson D, Parmar M. A randomised multicentre trial of CHART versus conventional radiotherapy in head and neck cancer. Radiother Oncol. 1997;44(2):123-136.

11. Horiot JC, Bontemps P, Bogaert W, et al. Accelerated fractionation (AF) compared to conventional fractionation (CF) improves loco-regional control in the radiotherapy of advanced head and neck cancers: results of the EORTC 22851 randomized trial. Radiother Oncol J Eur Soc Ther Radiol Oncol. 1997;44(2):111-121. Available from: http://onlinelibrary. wiley.com/o/cochrane/clcentral/articles/299/CN-00143299/frame.html

12. Brizel DM, Albers ME, Fisher SR, et al. Hyperfractionated irradiation with or without concurrent chemotherapy for locally advanced head and neck cancer. N Engl J Med. 1998;338(25):1798-1804.

13. Calais G, Alfonsi M, Bardet E, et al. Randomized trial of radiation therapy versus concomitant chemotherapy and radiation therapy for advanced-stage oropharynx carcinoma. J Natl Cancer Inst. 1999;91(24):2081-2086.

14. Shi XH, Yao W, Liu T. Late course accelerated fractionation in radiotherapy of esophageal carcinoma. Radiother Oncol J Eur Soc Ther Radiol Oncol. 1999;51(1):21-26. Available from: http://onlinelibrary. wiley.com/o/cochrane/clcentral/articles/670/CN-00164670/frame. html

15. Dobrowsky W, Naude J. Continuous hyperfractionated accelerated radiotherapy with/without mitomycin $\mathrm{C}$ in head and neck cancers. Radiother Oncol. 2000;57(2):119-124.
16. Fu KK, Pajak TF, Trotti A, et al. A Radiation Therapy Oncology Group (RTOG) phase III randomized study to compare hyperfractionation and two variants of accelerated fractionation to standard fractionation radiotherapy for head and neck squamous cell carcinomas: first report of RTOG 9003. Int J Radiat Oncol Biol Phys. 2000;48(1): $7-16$.

17. Jeremic B, Shibamoto Y, Milicic B, et al. Hyperfractionated radiation therapy with or without concurrent low-dose daily cisplatin in locally advanced squamous cell carcinoma of the head and neck: a prospective randomized trial. J Clin Oncol Off J Am Soc Clin Oncol. 2000;18(7):1458-1464.

18. Skladowski K, Maciejewski B, Golen M, Pilecki B, Przeorek W, Tarnawski R. Randomized clinical trial on 7-day-continuous accelerated irradiation (CAIR) of head and neck cancer - report on 3-year tumour control and normal tissue toxicity. Radiother Oncol. 2000;55(2): 101-110.

19. Teo PM, Leung SF, Chan AT, et al. Final report of a randomized trial on altered-fractionated radiotherapy in nasopharyngeal carcinoma prematurely terminated by significant increase in neurologic complications. Int J Rad Oncol Biol Phys. 2000;48(5):1311-1322.

20. Chua DTT, Sham JST, Wei WI, Ho WK, Au GKH. Alternating chemoradiotherapy versus partly accelerated radiotherapy in locally advanced squamous cell carcinoma of the head and neck: results from a phase III randomized trial. Cancer. 2001;92(11):2856-2867.

21. El-Weshi A, Khafaga Y, Allam A, et al. Neoadjuvant chemotherapy plus conventional radiotherapy or accelerated hyperfractionation in stage III and IV nasopharyngeal carcinoma: a phase II study. Acta Oncol (Stockholm, Sweden). 2001;40(5):574-581.

22. Poulsen MG, Denham JW, Peters LJ, et al. A randomised trial of accelerated and conventional radiotherapy for stage III and IV squamous carcinoma of the head and neck: a Trans-Tasman Radiation Oncology Group Study. Radiother Oncol. 2001;60(2):113-122.

23. Staar S, Rudat V, Stuetzer H, Dietz A, Volling P, Schroeder M. Erratum: intensified hyperfractionated accelerated radiotherapy limits the additional benefit of simultaneous chemotherapy. Results of a multicentric randomized German trial in advanced head-and-neck cancer (International Journal of Radiation Oncology Biology Physics 2001;50: 1161-1171)). Int J Radiat Oncol Biol Phys. 2001;51(2). Available from: http://onlinelibrary.wiley.com/o/cochrane/clcentral/articles/209/ CN-00783209/frame.html

24. Awwad HK, Lotayef M, Shouman T, et al. Accelerated hyperfractionation (AHF) compared to conventional fractionation (CF) in the postoperative radiotherapy of locally advanced head and neck cancer: influence of proliferation. Br J Cancer. 2002;86(4):517-523.

25. Bartelink H, Bogaert W, Horiot JC, Jager J, Glabbeke M. Concomitant cisplatin and radiotherapy in a conventional and modified fractionation schedule in locally advanced head and neck cancer: a randomised phase II EORTC trial. Eur J Cancer (Oxford, England: 1990). 2002;38(5):667-673. Available from: http://onlinelibrary.wiley.com/o/ cochrane/clcentral/articles/106/CN-00379106/frame.html

26. Gao XS, Qiao XY, Yang XR, et al. Late course accelerated hyperfractionation radiotherapy concomitant with cisplatin in patients with esophageal carcinoma. Oncol Rep. 2002;9(4):767-772.

27. Hliniak A, Gwiazdowska B, Szutkowski Z, et al. A multicentre random$\mathrm{ized} /$ controlled trial of a conventional versus modestly accelerated radiotherapy in the laryngeal cancer: influence of a 1 week shortening overall time. Radiother Oncol J Eur Soc Ther Radiol Oncol. 2002;62(1):1-10. Available from: http://onlinelibrary.wiley.com/o/cochrane/clcentral/ articles/673/CN-00377673/frame.html

28. Adelstein DJ, Li Y, Adams GL, et al. An intergroup phase III comparison of standard radiation therapy and two schedules of concurrent chemoradiotherapy in patients with unresectable squamous cell head and neck cancer. J Clin Oncol Off J Am Soc Clin Oncol. 2003;21(1):92-98.

29. Olmi P, Crispino S, Fallai C, et al. Locoregionally advanced carcinoma of the oropharynx: conventional radiotherapy vs. accelerated hyperfractionated radiotherapy vs. concomitant radiotherapy and chemotherapy: a multicenter randomized trial. Int J Radiat Oncol Biol Phys. 2003;55(1):78-92. 
30. Overgaard J, Hansen HS, Specht L, et al. Five compared with six fractions per week of conventional radiotherapy of squamous-cell carcinoma of head and neck: DAHANCA 6 and 7 randomised controlled trial. Lancet (London, England). 2003;362(9388):933-940.

31. Fountzilas G, Ciuleanu E, Dafni U, et al. Concomitant radiochemotherapy vs radiotherapy alone in patients with head and neck cancer: a Hellenic Cooperative Oncology Group Phase III Study. Med Oncol (Northwood, London, England). 2004;21(2):95-107.

32. Hehr T, Classen J, Schreck U, et al. Glocker S, Bamberg M, Budach W. Hyperfractionated accelerated radiotherapy alone and with concomitant chemotherapy to the head and neck: treated within and outside of randomized clinical trials. Int J Radiat Oncol Biol Phys. 2004;58(5):1424-1430.

33. Huguenin P, Beer KT, Allal A, et al. Concomitant cisplatin significantly improves locoregional control in advanced head and neck cancers treated with hyperfractionated radiotherapy. J Clin Oncol Off J Am Soc Clin Oncol. 2004;22(23):4665-4673.

34. Budach V, Stuschke M, Budach W, et al. Hyperfractionated accelerated chemoradiation with concurrent fluorouracil-mitomycin is more effective than dose-escalated hyperfractionated accelerated radiation therapy alone in locally advanced head and neck cancer: final results of the radiotherapy cooperative clinical trials group of the German Cancer Society 95-06 Prospective Randomized Trial. J Clin Oncol Off J Am Soc Clin Oncol. 2005;23(6):1125-1135.

35. Ezzat M, Shouman T, Zaza K, et al. A randomized study of accelerated fractionation radiotherapy with and without mitomycin $\mathrm{C}$ in the treatment of locally advanced head and neck cancer. $J$ Egypt Natl Cancer Inst. 2005;17(2):85-92.

36. Lee AW, Lau WH, Tung SY, et al. Preliminary results of a randomized study on therapeutic gain by concurrent chemotherapy for regionallyadvanced nasopharyngeal carcinoma: NPC-9901 Trial by the Hong Kong Nasopharyngeal Cancer Study Group. J Clin Oncol Off J Am Soc Clin Oncol. 2005;23(28):6966-6975.

37. Sanguineti G, Richetti A, Bignardi M, et al. Accelerated versus conventional fractionated postoperative radiotherapy for advanced head and neck cancer: results of a multicenter Phase III study. Int $J$ Radiat Oncol Biol Phys. 2005;61(3):762-771.

38. Zhao KL, Shi XH, Jiang GL, et al. Late course accelerated hyperfractionated radiotherapy plus concurrent chemotherapy for squamous cell carcinoma of the esophagus: a phase III randomized study. Int J Radiat Oncol Biol Phys. 2005;62(4):1014-1020.

39. Bensadoun RJ, Bénézery K, Dassonville O, et al. French multicenter phase III randomized study testing concurrent twice-a-day radiotherapy and cisplatin/5-fluorouracil chemotherapy (BiRCF) in unresectable pharyngeal carcinoma: results at 2 years (FNCLCC-GORTEC). Int J Radiat Oncol Biol Phys. 2006;64(4):983-994. Available from: http://onlinelibrary.wiley.com/o/cochrane/clcentral/articles/822/ $\mathrm{CN}-00553822 /$ frame.html

40. Bourhis J, Lapeyre M, Tortochaux J, et al. Phase III randomized trial of very accelerated radiation therapy compared with conventional radiation therapy in squamous cell head and neck cancer: a GORTEC trial. J Clin Oncol Off J Am Soc Clin Oncol. 2006;24(18):2873-2878.

41. Fallai C, Bolner A, Signor M, et al. Long-term results of conventional radiotherapy versus accelerated hyperfractionated radiotherapy versus concomitant radiotherapy and chemotherapy in locoregionally advanced carcinoma of the oropharynx. Tumori. 2006;92(1):41-54.

42. Semrau R, Mueller RP, Stuetzer H, et al. Efficacy of intensified hyperfractionated and accelerated radiotherapy and concurrent chemotherapy with carboplatin and 5-fluorouracil: updated results of a randomized multicentric trial in advanced head-and-neck cancer. Int J Radiat Oncol Biol Phys. 2006;64(5):1308-1316.

43. Skladowski K, Maciejewski B, Golen M, et al. Continuous accelerated 7-days-a-week radiotherapy for head-and-neck cancer: longterm results of phase III clinical trial. Int J Radiat Oncol Biol Phys. 2006;66(3):706-713.
44. Cummings B, Keane T, Pintilie M, et al. Five year results of a randomized trial comparing hyperfractionated to conventional radiotherapy over four weeks in locally advanced head and neck cancer. Radiother Oncol. 2007;85(1):7-16.

45. Daoud J, Toumi N, Siala W, et al. Ghorbel A, Drira MM, Frikha M. Results of a prospective randomised trial comparing conventional radiotherapy to split course bifractionated radiation therapy in patients with nasopharyngeal carcinoma. Radiother Oncol J Eur Soc Ther Radiol Oncol. 2007;85(1):17-23. Available from: http:/onlinelibrary. wiley.com/o/cochrane/clcentral/articles/787/CN-00617787/frame. html

46. Katori H, Tsukuda M, Watai K. Comparison of hyperfractionation and conventional fractionation radiotherapy with concurrent docetaxel, cisplatin and 5-fluorouracil (TPF) chemotherapy in patients with locally advanced squamous cell carcinoma of the head and neck (SCCHN). Cancer Chemother Pharmacol. 2007;60(3):399-406.

47. Ghoshal S, Goda JS, Mallick I, Kehwar TS, Sharma SC. Concomitant boost radiotherapy compared with conventional radiotherapy in squamous cell carcinoma of the head and neck - a phase III trial from a single institution in India. Clin Oncol (Royal College of Radiologists (Great Britain)). 2008;20(3):212-220.

48. Overgaard J, Mohanti BK, Begum N, et al. Five versus six fractions of radiotherapy per week for squamous-cell carcinoma of the head and neck (IAEA-ACC study): a randomised, multicentre trial. Lancet Oncol. 2010;11(6):553-560.

49. Saunders MI, Rojas AM, Parmar MK, Dische S. Mature results of a randomized trial of accelerated hyperfractionated versus conventional radiotherapy in head-and-neck cancer. Int J Radiat Oncol Biol Phys. 2010;77(1):3-8.

50. Bourhis J, Lapeyre M, Tortochaux J, et al. Accelerated radiotherapy and concomitant high dose chemotherapy in non resectable stage IV locally advanced HNSCC: results of a GORTEC randomized trial. Radiother Oncol. 2011;100(1):56-61.

51. Lee AW, Tung SY, Chan AT, et al. A randomized trial on addition of concurrent-adjuvant chemotherapy and/or accelerated fractionation for locally-advanced nasopharyngeal carcinoma. Radiother Oncol. 2011;98(1):15-22.

52. Zackrisson B, Nilsson P, Kjellen E, et al. Two-year results from a Swedish study on conventional versus accelerated radiotherapy in head and neck squamous cell carcinoma - the ARTSCAN study. Radiother Oncol. 2011;100(1):41-48.

53. Bourhis J, Sire C, Graff P, et al. Concomitant chemoradiotherapy versus acceleration of radiotherapy with or without concomitant chemotherapy in locally advanced head and neck carcinoma (GORTEC 99-02): an open-label phase 3 randomised trial. Lancet Oncol. 2012;13(2): 145-153. Available from: http://onlinelibrary.wiley.com/o/cochrane/ clcentral/articles/727/CN-00857727/frame.html

54. Ghadjar P, Simcock M, Studer G, Allal AS, Ozsahin M, Bernier J. Concomitant cisplatin and hyperfractionated radiotherapy in locally advanced head and neck cancer: 10-year follow-up of a randomized phase III trial (SAKK 10/94). Int J Radiat Oncol Biol Phys. 2012;82(2):524-531. Available from: http://onlinelibrary.wiley.com/o/ cochrane/clcentral/articles/711/CN-00857711/frame.html

55. Liu M, Shi X, Guo X, et al. Long-term outcome of irradiation with or without chemotherapy for esophageal squamous cell carcinoma: a final report on a prospective trial. Radat Oncol (London, England). 2012;7:142.

56. Pan ZQ, He XY, Guo XM, et al. A phase III study of late course accelerated hyperfractionated radiotherapy versus conventionally fractionated radiotherapy in patients with nasopharyngeal carcinoma. Am J Clin Oncol. 2012;35(6):600-605.

57. Wang JH, Lu XJ, Zhou J, Wang F. A randomized controlled trial of conventional fraction and late course accelerated hyperfraction three-dimensional conformal radiotherapy for esophageal cancer. Cell Biochem Biophys. 2012;62(1):107-112. 
58. Chitapanarux I, Kamnerdsupaphon P, Pukanhapan N, Tharavichitkul E, Vongtama R. Randomized phase III trial of concurrent chemoradiotherapy vs accelerated hyperfractionation radiotherapy in locally advanced head and neck cancer. $J$ Rad Res. 2013;54(6):1110-1117. Available from: http://onlinelibrary.wiley.com/o/cochrane/clcentral/articles/857/ CN-00987857/frame.html

59. Ghadjar P, Sun H, Zimmermann F, et al. Physical examination during chemoradiation predicts outcome of locally advanced head and neck cancer. Secondary results of a randomized phase III trial (SAKK 10/94). Oral Oncol. 2013;49(10):1006-1009.

60. Majumder D, Choudhury K, Das P, Kundu S, Mitra D. Different fractionation schedules of radiotherapy in locally advanced head and neck malignancy: a prospective randomized study to compare the results of treatment and toxicities of different protocols. South Asian J Cancer. 2013;2(1):31-35.

61. Beitler JJ, Zhang Q, Fu KK, et al. Final results of local-regional control and late toxicity of RTOG 9003: a randomized trial of altered fractionation radiation for locally advanced head and neck cancer. Int J Radiat Oncol Biol Phys. 2014;89(1):13-20.

62. Miszczyk L, Maciejewski B, Tukiendorf A, et al. Split-course accelerated hyperfractionated irradiation (CHA-CHA) as a sole treatment for advanced head and neck cancer patients-final results of a randomized clinical trial. Br J Radiol. 2014;87(1041):20140212. Available from: http://onlinelibrary.wiley.com/o/cochrane/clcentral/articles/204/ CN-00997204/frame.html

63. Nguyen-Tan PF, Zhang Q, Ang KK, et al. Randomized phase III trial to test accelerated versus standard fractionation in combination with concurrent cisplatin for head and neck carcinomas in the Radiation Therapy Oncology Group 0129 trial: long-term report of efficacy and toxicity. J Clin Oncol Off J Am Soc Clin Oncol. 2014;32(34):3858-3866.

64. Trotti A 3rd, Zhang Q, Bentzen SM, et al. Randomized trial of hyperfractionation versus conventional fractionation in T2 squamous cell carcinoma of the vocal cord (RTOG 9512). Int J Radiat Oncol Biol Phys. 2014;89(5):958-963.

65. Budach V, Stromberger C, Poettgen C, et al. Hyperfractionated accelerated radiation therapy (HART) of 70.6 Gy with concurrent 5-FU/ Mitomycin C is superior to HART of 77.6 Gy alone in locally advanced head and neck cancer: long-term results of the ARO 95-06 randomized phase III trial. Int J Rad Oncol Biol Phys. 2015;91(5):916-924. Available from: http://onlinelibrary.wiley.com/o/cochrane/clcentral/ articles/376/CN-01043376/frame.html
66. Gupta M, Vats S, Bhattacharyya T, et al. Seem RK, Gupta M, Mahajan R Prospective randomized trial to compare the outcome and tolerability of delivering the same total dose of radiation in 61/2 weeks versus 51/2 weeks time in head and neck cancers. South Asian J Cancer. 2015; 4(3):118-122.

67. Kong F, Cai B, Lin S, et al. Assessment of radiotherapy combined with adjuvant chemotherapy in the treatment of patients with advanced nasopharyngeal carcinoma: a prospective study. J B.U.ON. Off J Balkon Union Oncol. 2015;20(1):206-211. Available from: http://onlinelibrary. wiley.com/o/cochrane/clcentral/articles/834/CN-01072834/frame. html

68. Lee AWM, Ngan RKC, Tung SY, et al. Preliminary results of trial NPC-0501 evaluating the therapeutic gain by changing from concurrentadjuvant to induction-concurrent chemoradiotherapy, changing from fluorouracil to capecitabine, and changing from conventional to accelerated radiotherapy fractionation in patients with locoregionally advanced nasopharyngeal carcinoma. Cancer. 2015;121(8):1328-1338.

69. Lyhne NM, Primdahl H, Kristensen CA, et al. The DAHANCA 6 randomized trial: effect of 6 vs 5 weekly fractions of radiotherapy in patients with glottic squamous cell carcinoma. Radiother Oncol J Eur Soc Ther Radiol Oncol. 2015;117(1):91-98. Available from: http://onlinelibrary.wiley.com/o/cochrane/clcentral/articles/769/ CN-01105769/frame.html

70. Zackrisson B, Kjellén E, Söderström K, et al. Mature results from a Swedish comparison study of conventional versus accelerated radiotherapy in head and neck squamous cell carcinoma - The ARTSCAN trial. Radiother Oncol. 2015;117(1):99-105.

71. Alam MS, Perween R, Siddiqui SA. Comparison of two different radiation fractionation schedules with concurrent chemotherapy in head and neck malignancy. Ind J Cancer. 2016;53(2):265-269.

72. Ghosh-Laskar S, Kalyani N, Gupta T, et al. Conventional radiotherapy versus concurrent chemoradiotherapy versus accelerated radiotherapy in locoregionally advanced carcinoma of head and neck: Results of a prospective randomized trial. Head Neck. 2016;38(2):202-207. Available from: http://onlinelibrary.wiley.com/o/cochrane/clcentral/ articles/485/CN-01043485/frame.html
OncoTargets and Therapy

\section{Publish your work in this journal}

OncoTargets and Therapy is an international, peer-reviewed, open access journal focusing on the pathological basis of all cancers, potential targets for therapy and treatment protocols employed to improve the management of cancer patients. The journal also focuses on the impact of management programs and new therapeutic agents and protocols on

\section{Dovepress}

patient perspectives such as quality of life, adherence and satisfaction. The manuscript management system is completely online and includes a very quick and fair peer-review system, which is all easy to use. Visit http://www.dovepress.com/testimonials.php to read real quotes from published authors. 